Japan. J. Med. Sci. Biol., 31, 53-79, 1978

\title{
COMPARATIVE STUDIES ON EFFECTS OF INCOMPLETE OIL ADJUVANTS WITH DIFFERENT PHYSICAL PROPERTIES*
}

\author{
NORIHISA GOTO \\ Department of General Biologics Control, National Institute of Health, \\ Kamiosaki, Shinagawa-ku, Tokyo 141, Japan
}

(Received: June 29, 1977)

\begin{abstract}
SUMMARY: The author investigated the effects of Freund's incomplete adjuvant (FIA) with different physical properties on precipitin formation and skin hyperreactivity in rabbits and mice following intramuscular injection of ovalbumin (OA) with the adjuvant. Histopathological changes in the injection site and in some visceral organs were also examined. The observation periods after the injection for mice and rabbits were 20 and 28 weeks, respectively.

In contrast to the most reports, FIA of both imperfectly emulsified-water-in-oil (W/O II) and oil-in-water $(\mathrm{O} / \mathrm{W})$ types were sometimes equivalent or superior to perfectly emulsified water-in-oil (W/O I) type FIA in the enhancing effects on precipitin formation both in rabbits and mice. The skin displayed the immediate type hypersensitivity reaction to $\mathrm{OA}$ throughout the observation period irrespective of the type of adjuvant. The $\mathrm{O} / \mathrm{W}$ type often caused significantly stronger skin hyperreactivity than the other types.

Histopathological findings in the injection site indicated that the abscess formation in rabbits was severer than that in mice, and that the $O / W$ type induced the severest abscess. No relation was found between free fatty acid contents of adjuvant emulsion and abscess formation in either animal species. Granuloma formation in mice was always severer than that in rabbits. The $O / W$ type caused extremely weak granuloma in mice, and none in rabbits. Histopathological changes in main visceral organs, being dependent on the emulsion type, were also discussed.
\end{abstract}

\section{INTRODUCTION}

Freund's adjuvants have widely been used in the immunological fields for many years. Freund's complete adjuvant (FCA) is not used in man because of its severe reactogenicity, while Freund's incomplete adjuvant (FIA) has been tested in man for some viral antigens, such as influenza (Henle and Henle, 1945; Medical Research Council, 1964), poliomyelitis (Salk et al., 1951; Cutler, Lesesne and Vaughn, 1962), adeno (Meiklejohn, 1962) and trachoma (Grayston et al., 1964) vaccines, bacterial antigens, such as cholera (Philippines Cholera Committee, 1965; Ogonuki, Hashizume and Abe, 1967) and typhoid (Snyder et al., 1966) vaccines and tetanus toxoid (MacLennan et al., 1965). Though it en-

\footnotetext{
* This study was presented in part at the 36th Meeting of Kanto Region of the Japanese Society for Bacteriology, Tokyo, 1976.

後藤紀久（国立予防衛生研究所 一般検定部）
} 
hanced antibody formation, granuloma and abscess formation and other side reactions have often been noted.

Investigations in experimental animals for the effects of FIA on antibody formation, allergic reaction, local and systemic histopathological changes have been reported (Friedewald, 1944; Fischel et al., 1952; Hilleman, Hampil and Sweet, 1963; Carter, Jamison and Vollum, 1968). These reports may not assess the effects of the composition and properties of the adjuvant and the role of experimental factors. Adjuvant components, administration routes, antigens and animal species used varied from one report to another, the items of observation carried out in some reports were too limited and the observation period was too short. Much remains to be elucidated on the relationship between the immune response-enhancing functions and the harmful activities of oil adjuvant.

There have been few reports on the direct relationships between adjuvant actions and physical properties of mineral oil adjuvant emulsions. Berlin (1960) concluded that the maximum antibody enhancement of FIA was associated with an optimal range of viscosity of the emulsion as measured by flow rates. As to the relation between abscess formation and chemical compositions or physical properties of adjuvant, Hardegree and Pittman (1967) inferred that free oleic acid may induce abscess, while MacLennan et al. (1965) suggested that separation of water and oil phases might be the cause. No confirmatory report, however, has appeared.

We intended a comprehensive study on the relation between physical properties of oil emulsion and the immunological response-enhancing functions as well as possible injurious action of FIA using guinea pigs, rabbits and mice. The findings obtained in guinea pigs have been reported (Goto et al., 1972, 1973, 1974a,b). The present report deals with the results in rabbits and mice. Those in guinea pigs are referred, when necessary.

Histopathological examinations of the injection site and visceral organs of animals injected with adjuvant were carried out. This report presents only such histopathological findings as those seemed to be related to the main subjects mentioned above. More detailed descriptions of the histopathological changes will be presented in separate reports.

\section{Materials ANd Methods}

Animals: Female rabbits of Japanese white, weighing 2.5 to $3 \mathrm{~kg}$, purchased from Japan Laboratory Animals Corporation, Tokyo, and about 5-week-old female mice of a conventional random bled stock (dd-Shizuoka) purchased from Shizuoka Jikken-Dobutsu Co., Shizuoka, were employed.

Antigen: The antigen used was ovalbumin (OA) (grade III, Wako Pure Chemical Industries, Osaka). Five milligrams and $25 \mathrm{mg}$ of $\mathrm{OA}$ in $1 \mathrm{ml}$ of physiological saline were prepared for rabbits and mice, respectively. The OA solution was sterilized by Millipore filtration $(0.45 \mu \mathrm{m})$. 
TABLE I

Composition, condition of emulsification and physical properties of emulsion types

\begin{tabular}{|c|c|c|c|c|c|c|c|c|c|c|}
\hline \multirow{3}{*}{$\begin{array}{l}\text { Emul- } \\
\text { sion } \\
\text { type }\end{array}$} & \multirow{2}{*}{\multicolumn{4}{|c|}{ Composition (v/v \%) }} & \multirow{2}{*}{\multicolumn{2}{|c|}{$\begin{array}{l}\text { Conditions } \\
\text { of emulsi- } \\
\text { fication }\end{array}$}} & \multicolumn{4}{|c|}{ Physical properties } \\
\hline & & & & & & & \multirow{2}{*}{$\begin{array}{l}\text { Proper-4) } \\
\text { ties of } \\
\text { particle }\end{array}$} & \multirow{2}{*}{$\begin{array}{l}\text { Diffusi- } \\
\text { bility }\end{array}$} & \multirow{2}{*}{$\begin{array}{l}\text { Separation } \\
\text { ratio of } \\
\text { oil }\end{array}$} & \multirow{2}{*}{$\begin{array}{c}\text { Viscosity } \\
\text { of } \\
\text { emulsion }\end{array}$} \\
\hline & $\mathrm{OA}^{1)}$ & Saline $\mathrm{e}^{2)}$ & $\begin{array}{c}\text { Drakeol }^{3)} \\
6\end{array}$ & $\begin{array}{c}\text { Arlacel }^{3)} \\
\text { A }\end{array}$ & $\mathrm{rpm}$ & $\min$ & & & & \\
\hline W/O I & 50 & 0 & 45 & 5 & 18,000 & 10 & $\begin{array}{l}\text { Fine } \\
\text { and } \\
\text { uniform }\end{array}$ & - & $2.1 \%$ & $65 \mathrm{P}^{6)}$ \\
\hline W/O II & 50 & 0 & 45 & 5 & 13,500 & 0.5 & $\begin{array}{l}\text { Fused } \\
\text { and } \\
\text { ununiform }\end{array}$ & + & $\begin{array}{c}\text { Not } \\
\text { measurable }\end{array}$ & $0.4 \mathrm{P}$ \\
\hline W/O III & 0 & 50 & 45 & 5 & 18,000 & 10 & $\begin{array}{l}\text { Fine } \\
\text { and } \\
\text { uniform }\end{array}$ & - & $2.0 \%$ & $66 \mathrm{P}$ \\
\hline $\mathrm{O} / \mathrm{W}$ & 50 & 40 & 9 & 1 & 20,000 & 5 & $\begin{array}{l}\text { Circular } \\
\text { oil droplets } \\
\text { in water } \\
\text { phase }\end{array}$ & $\mathrm{ND}^{5)}$ & $\mathrm{ND}$ & $3.0 \mathrm{CP}^{7)}$ \\
\hline
\end{tabular}

1) 0 A solution in saline: $5 \mathrm{mg} / \mathrm{ml}$ (rabbit); $0 \mathrm{~A}: 25 \mathrm{mg} / \mathrm{ml}$ (mouse), 2) $0.85 \% \mathrm{NaCl}$ solution,

3) These two materials were mixed at Chiba Serum Institute at ratios shown below, 4) See Fig. 1, 5) Not done, 6) Poise, 7) Centi poise.

Adjuvants: Drakeol 6 VR (Pennsylvania Refining Co., Butler, PA, U.S.A.) used was pure light liquid petrolatum. The emulsifier was Arlacel A 71-B (mannide monooleate; Atlas Chemical Industries, Inc., Wilmington, DE, U.S.A.), consisting principally of ester of mannitol and oleic acid. Nine parts of Drakeol and 1 part of Arlacel A were mixed and sterilized by passing through a Seitz filter ST 3 under compression of nitrogen gas. This adjuvant material was blended and supplied by courtesy of Mr. T. Tsurumizu of Chiba Serum Institute, Ichikawa, Chiba prefecture, designated as CSI adjuvant and used throughout the experiments, unless otherwise mentioned. With the adjuvant, the following four types of emulsion were prepared (Table I): Perfectly emulsified water in oil (W/O I), imperfectly emulsified water in oil (W/O II), oil in water $(\mathrm{O} / \mathrm{W})$ and perfectly emulsified water in oil without $\mathrm{OA}(\mathrm{W} / \mathrm{O}$ III). The composition materials at the stated ratio in Table I. placed in a cup, $34 \mathrm{~mm}$ in inside diameter, were emulsified with a homogenizer, HB-A (Nihon Seiki Kaisha, Tokyo) under the defined conditions (Table I). The rate of rotation was measured with a hand electric tachometer, HT-I Type (Tokyo Shibaura Electric Co., Tokyo). Difco adjuvant (Difco Laboratories, Detroit, MI, U.S.A.), consisting of 8.5 parts of Bayol F and 1.5 parts of Arlacel A, was used as control of each four emulsion types in mouse experiments. The compositions are summarized in Table II.

Physical properties of emulsion: The following physical properties of the emulsions were examined:

1) The properties of oil or water particles were examined by phase contrast microscopy. The microscopical examination was performed on the thin sheet made by compressing a drop of emulsion between a microscopic slide and a 
TABLE II

Composition of emulsion types made of Difco adjuvant

\begin{tabular}{lrccc}
\hline \multirow{2}{*}{$\begin{array}{c}\text { Emulsion } \\
\text { type }\end{array}$} & \multicolumn{4}{c}{ Composition (v/v \%) } \\
\cline { 2 - 5 } & OA* $^{*}$ & Saline* & Bayol F & Arlacel A \\
\hline W/O I & 50 & 0 & 42.5 & 7.5 \\
W/O II & 50 & 0 & 42.5 & 7.5 \\
W/O III & 0 & 50 & 42.5 & 7.5 \\
O/W & 50 & 40 & 8.5 & 1.5 \\
\hline
\end{tabular}

* See the legend to Table I.

coverslip.

2) The diffusibility was determined by the drop method. One drop of emulsion expressed from the tip of a hypodermic needle (1/1) from a height of at least $5 \mathrm{~cm}$ was permitted to fall on the surface of clear water in a petri dish maintained at $20 \mathrm{C}$; the presence or the absence of dispersion of the drop on the surface was recorded.

3) The separation ratio of oil was tested by the centrifugation method. The emulsion placed in a tube $(7 \mathrm{~mm}$ in inside diameter) was centrifuged at 3,000 rpm for $20 \mathrm{~min}$ and the ratio of the thickness of the oil-phase separated to the total height of the emulsion was taken as the separation ratio.

4) The viscosity of emulsion was measured in a No. 1 roter (for W/O I and W/O III types) and in a No. 3 roter (for W/O II type) with a viscotester, Type VT-02 (Rion, Co., Tokyo). The O/W type was measured in a No. 4 roter with another viscotester, Type VT-01. The viscosity was measured five times and the mean value is presented in the table.

Determination of free fatty acid $(F F A)$ : FFA was determined by the method described by Vaughan, Berger and Steinberg (1964) and expressed in micromoles calculated on the basis of a standard palmitic acid curve.

Analysis for FFA composition of Arlacel $A$ and CSI adjuvant: Lipids in Arlacel $\mathrm{A}$ and adjuvant were separated by thin layer chromatography on silica gel with a developing solvent of petroleum ether: ethyl ether:acetic acid (82:18:1). The band of FFA was scraped off and extracted with chloroform: methanol (2:1). FFA was methylated by the treatment with diazomethane in ethyl ether and methanol at room temperature and the resulting esters were subjected to gas-liquid chromatography in a Shimazu GC-1C instrument using $2.25-\mathrm{m}$ columns of diethylene glycol succinate on Chromosorb $\mathrm{W}$ at $170 \mathrm{C}$. The nitrogen flow rate was $35 \mathrm{ml} / \mathrm{min}$. They were identified by comparison of their retention times with those of the standards. The proportions of fatty acids were determined by cutting out peaks and weighing them.

Immunization: Two series of groups of rabbits were injected with the materials; one was composed of five groups of 32 rabbits each and used for obtaining the kinetics of precipitin formation and histopathological examinations, and the other consisting of four groups of 16 rabbits each was used for 
obtaining the kinetics of skin reactivity. The former series were each given a single intramuscular (right femur) injection of $0.5 \mathrm{ml}$ of each emulsion type and the OA-saline solution (OA-alone). The latter series were each injected with $\mathrm{W} / \mathrm{O} \mathrm{I}, \mathrm{W} / \mathrm{O} \mathrm{II}, \mathrm{O} / \mathrm{W}$ or OA alone in the same way. Two series of groups each consisting of five groups of 35 mice each received CSI and Difco adjuvants, respectively. The animals were injected in the same manner as the former series of rabbits except for that the dose was $0.1 \mathrm{ml}$ containing $1.25 \mathrm{mg}$ of OA.

Precipitin titration: Three rabbits in each group of the former series were bled at a time from the ear vein 2, 4, 8, 10, 16, 20, 24 and 28 weeks after immunization. Five mice in each group were bled from the heart $72 \mathrm{hr}$ and $1,2,4,8,16$ and 20 weeks after immunization. The precipitin titer was measured by the ring method at a concentration of $250 \mu \mathrm{g} / \mathrm{ml}$ of OA. The precipitin titers were expressed as the highest dilution showing positive precipitation. The 2-mercaptoethanol (ME)-resistant precipitin was assayed in the same way as above with a mixture of equal volumes of serum and $0.2 \mathrm{M} \mathrm{ME}$ incubated in a water bath at $37 \mathrm{C}$ for $30 \mathrm{~min}$.

The precipitin titers were transformed into logarithms to base 2 for statistical analysis.

Histopathological examinations: Two or five rabbits from each group of the former series of immunization were killed at a time $72 \mathrm{hr}$ and 1, 2, 4, 8, 16 and 20 weeks after injection. Besides, two other rabbits were killed in $72 \mathrm{hr}$ and 1, 2 and 8 weeks. After macroscopical observation of the adjuvant remnants at the injection site, the following tissue and organs were removed: the injection site (muscle), regional inguinal lymph nodes, lungs, liver, spleen and kidneys. Three mice in each group were also killed at a time by bleeding from the heart for precipitin titration and the following organs were removed: adrenal glands, thymus and heart, in addition to the above-mentioned organs. The organs were fixed in $10 \%$ neutral formalin, embedded in paraffin, stained with hematoxylin and eosin (H-E), and with periodic acid-Schiff and Masson (modification of the Goldner), when necessary.

Skin test: The skin test was performed on two rabbits from each emulsion group of the latter series 2; 3, 6, 10, 12, 16, 20 and 24 weeks after sensitization. The back of the rabbit was shaved and divided into 8 sections, 7 of which were intradermally inoculated with $10 \mu \mathrm{g}$ of $\mathrm{OA}$ in $0.1 \mathrm{ml}$ of saline and the 8 th with $0.1 \mathrm{ml}$ of saline as a control. Reaction was measured 3, 6, 9, 24 and $48 \mathrm{hr}$ after injection and the average crossdiameter in $\mathrm{mm}$ of erythema in each section was recorded. The skin sites showing the maximum and minimum sizes of erythema in each group were removed and processed for microscopic observation with H-E staining. 

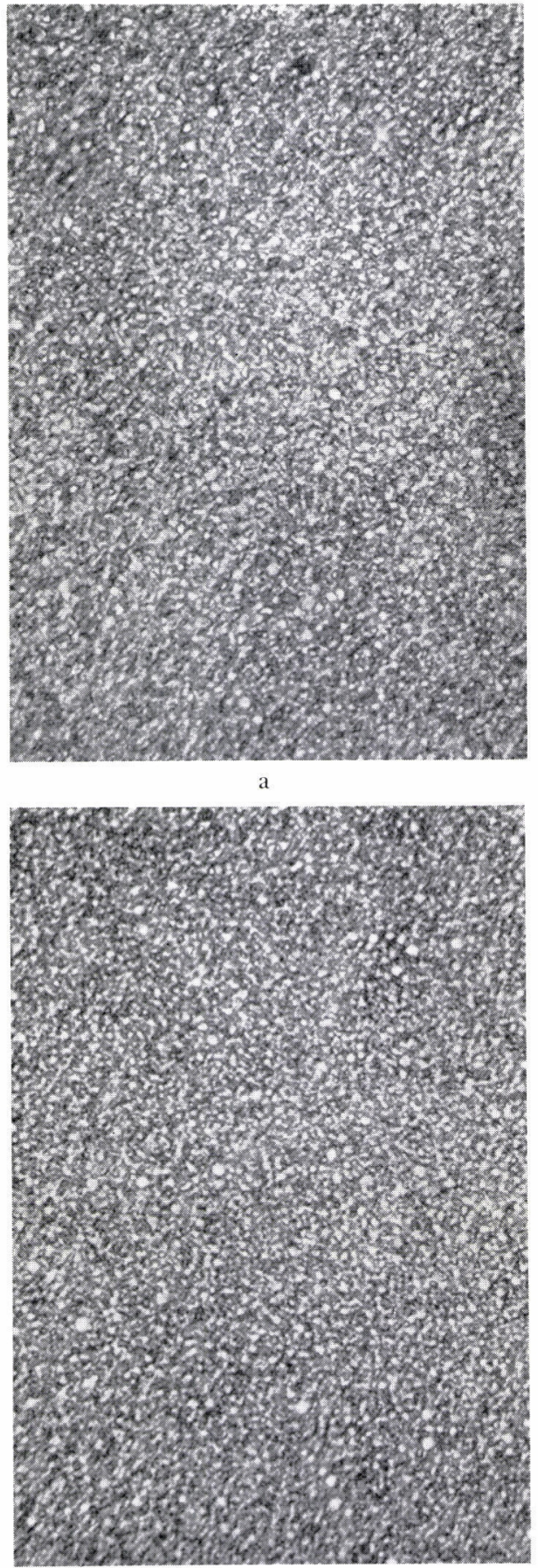

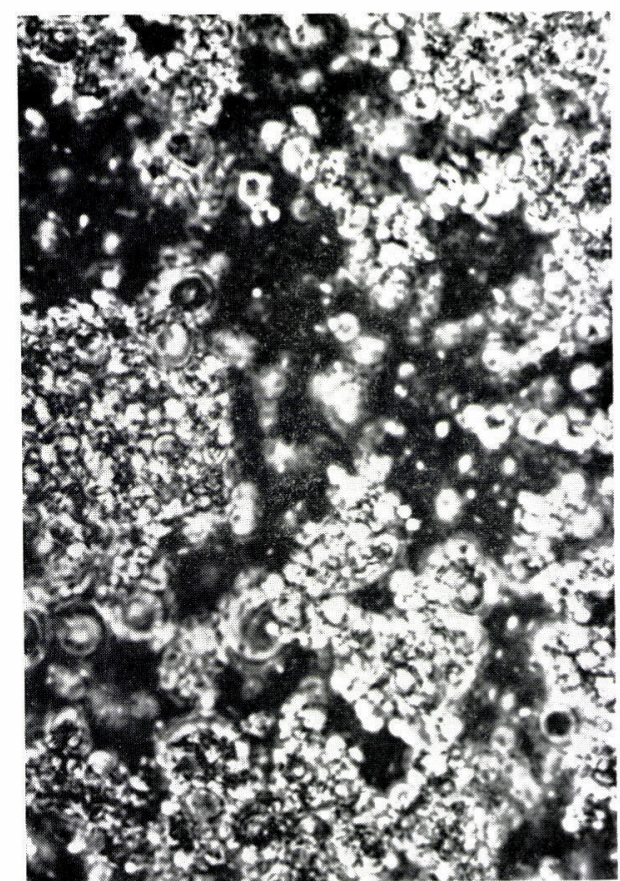

b)

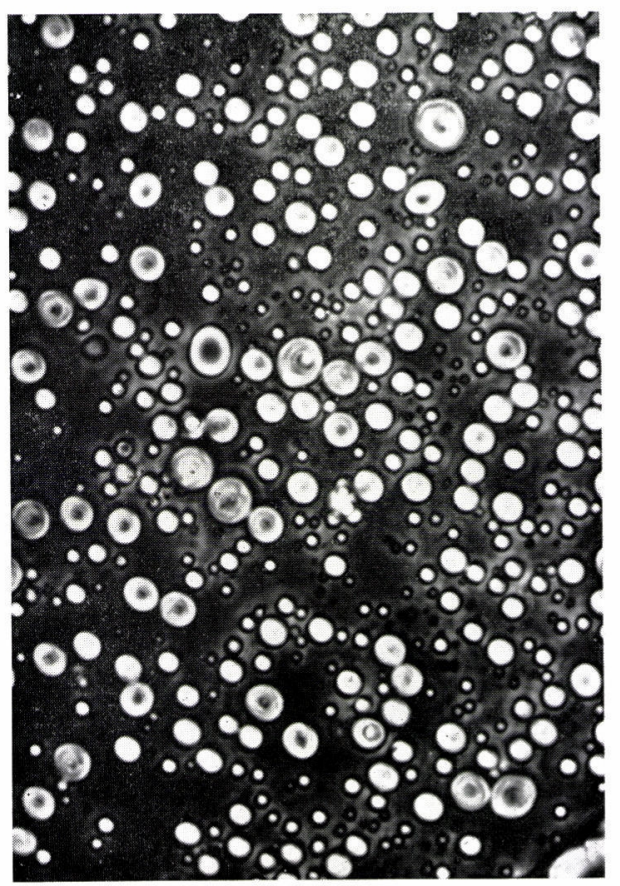

Fig. 1. Phase contrast microscopic photographs of oil emulsions. Symbols: a (W/O I type), b (W/O II type), c (W/O III type), d (O/W type). $\times 600$. 


\section{RESUlts \\ Physical Properties of Emulsion of Different Types}

The physical properties of emulsions are summarized in Table I. Phase contrast microscopic properties of oil and water particles are presented in Fig. 1. There was not much difference in the physical properties between CSI and Difco adjuvants. Table I shows those of former adjuvant only.

\section{Kinetics of Precipitin Titer after Immunization}

1. Rabbits: Kinetics of the precipitin titer in rabbits are shown in Fig. 2. The W/O I type group maintained a fairly constant antibody level for 28 weeks, while the W/O II type group displayed two peaks. The pattern of the $\mathrm{O} / \mathrm{W}$ type group was similar to that of the W/O I type group but more fluctuant than that of the latter. The precipitin titer of the OA-alone group reached a peak at week 4 and was undetectable after 8 weeks.

No 2-ME-resistant antibody was demonstrated in the W/O I type group within 8 weeks. The antibody titers in 10 to 20 weeks were accounted for mostly by ME-resistant ones, which then decreased. In the W/O II type group, the ME-resistant antibodies appeared in 4 weeks and were the majority of the antibody titer in 20 weeks. In the $\mathrm{O} / \mathrm{W}$ type group, the resistant antibodies were detected first at week 8 , as in the W/O I type group. In the OA-alone group, the time course of the titers of ME-untreated sera gave a pattern similar, though not so clear, to the first peak of the W/O II type group.

2. Mice: The kinetics of the precipitin titer in mice are shown in Figs. 3 and 4 .

i. CSI adjuvant: There was not much difference in the pattern of kinetics of precipitin titer among the emulsion-type groups (Fig. 3). The antibodies were detected as early as a week after immunization in all groups. The titer gradually rose to a peak at week 8 or 16 in all groups except the W/O II type group that gave a peak at week 2 . In the OA-alone group, the precipitin titer reached its peak at week 2 and then declined below the detectable level in 8 weeks. An early antibody response of the OA-alone group only for a short period was a common phenomenon seen in the rabbit and the mouse.

No ME-resistant antibodies were demonstrated in 1 week; and more than half of the antibody titers were accounted for by the ME-resistant antibodies in 2 weeks except in the $\mathrm{O} / \mathrm{W}$ type group.

ii. Difco adjuvant: As shown in Fig. 4, the Difco-adjuvant group exhibited kinetics of antibody similar to those of the CSI adjuvant group. The $\mathrm{O} / \mathrm{W}$ type group of the former adjuvant showed relatively high titers of MEsensitive antibodies, while no antibodies were demonstrated in the W/O I type group at week 1 . 


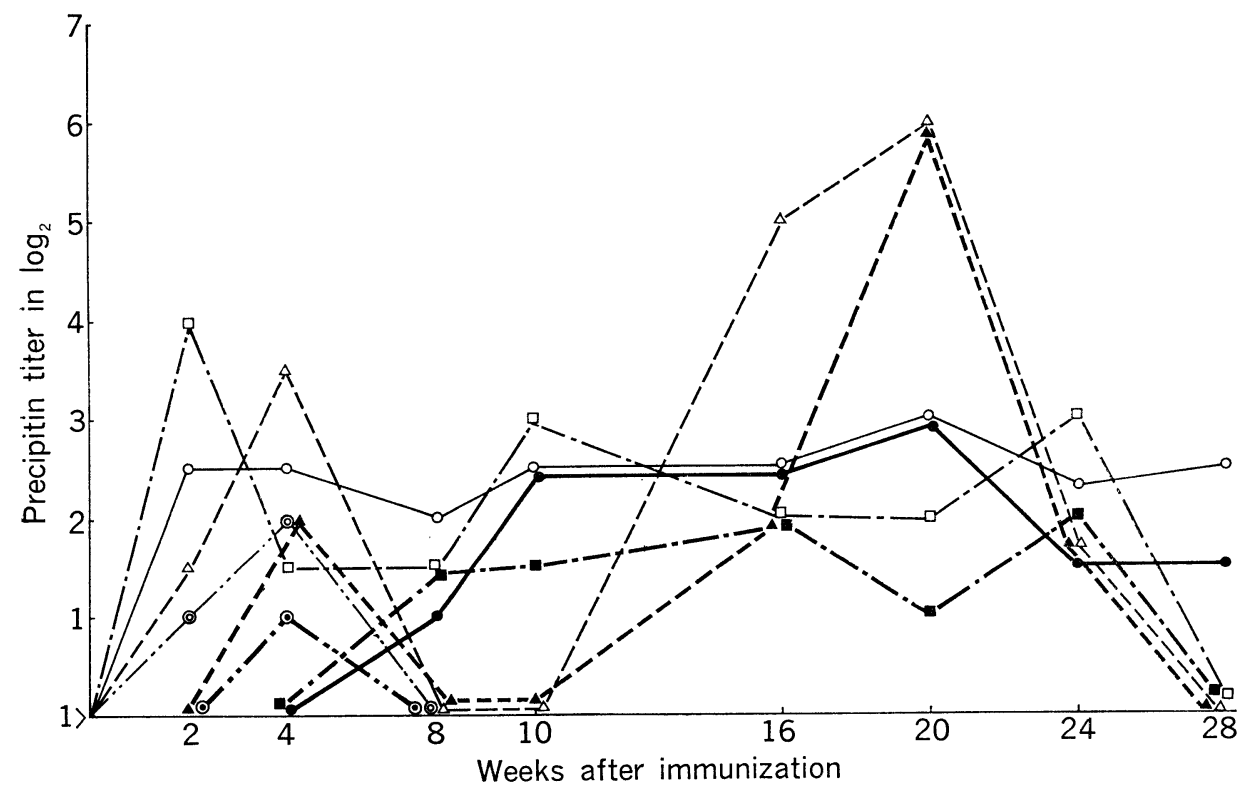

Fig. 2. Precipitin titers in rabbits.

Rabbits were immunized by im injection of $0.5 \mathrm{ml}$ of each emulsion containing $1.25 \mathrm{mg}$ of OA. Each symbol represents mean precipitin titer of three rabbits as measured before (faint lines and open symbols) or after (heavy lines and closed symbols) 2-ME treatment. -O- - - - W/O I; - - $\triangle----\Delta--$, W/O II; - - - ----$\mathrm{O} / \mathrm{W}$; - - - $-\mathrm{O}---\cdots$

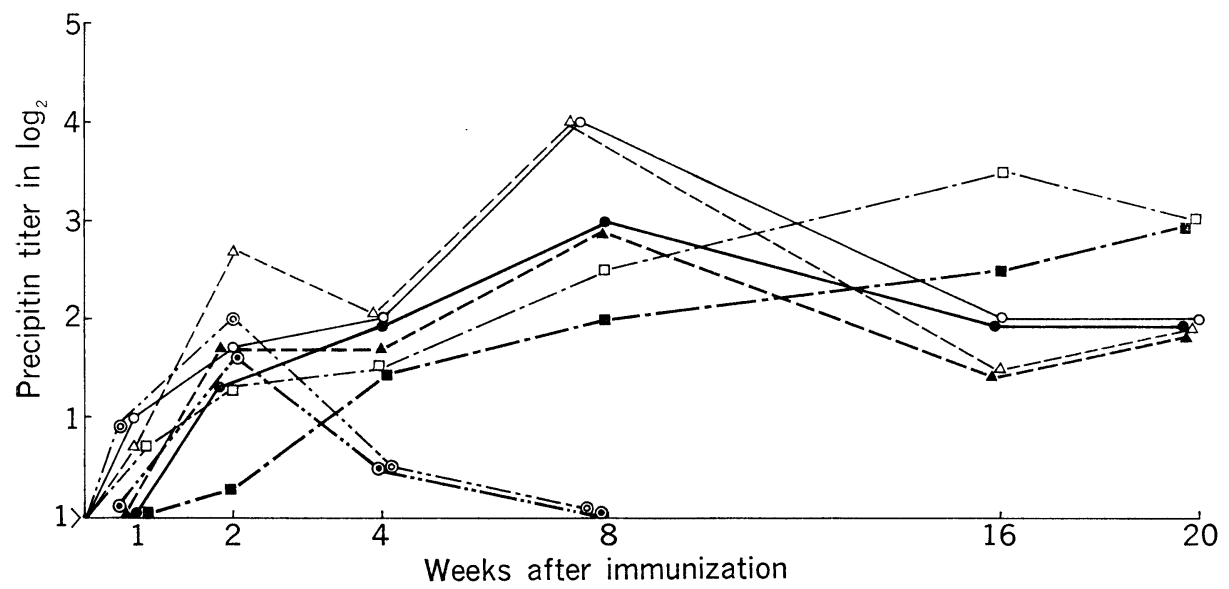

Fig. 3. Precipitin titers in mice.

Mice were immunized by im injection of $0.1 \mathrm{ml}$ of each emulsion containing $1.25 \mathrm{mg}$ of OA. Each symbol represents mean precipitin titer of five mice. For symbols, see the legend to Fig. 2. 


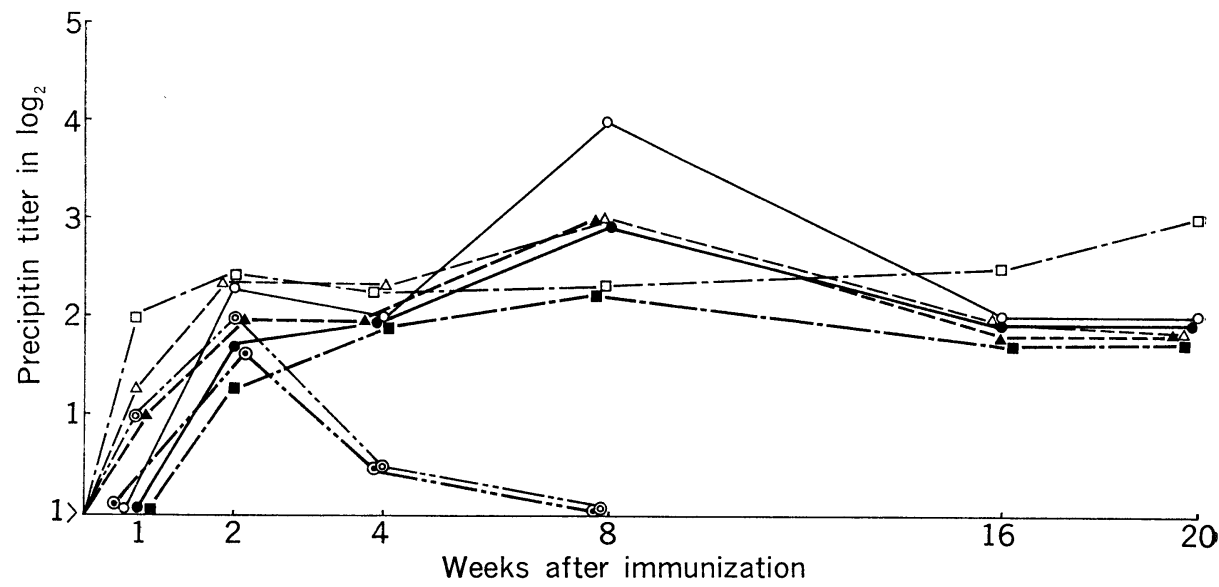

Fig. 4. Precipitin titer in mice (Difco adjuvant).

See the legend to Fig. 3.

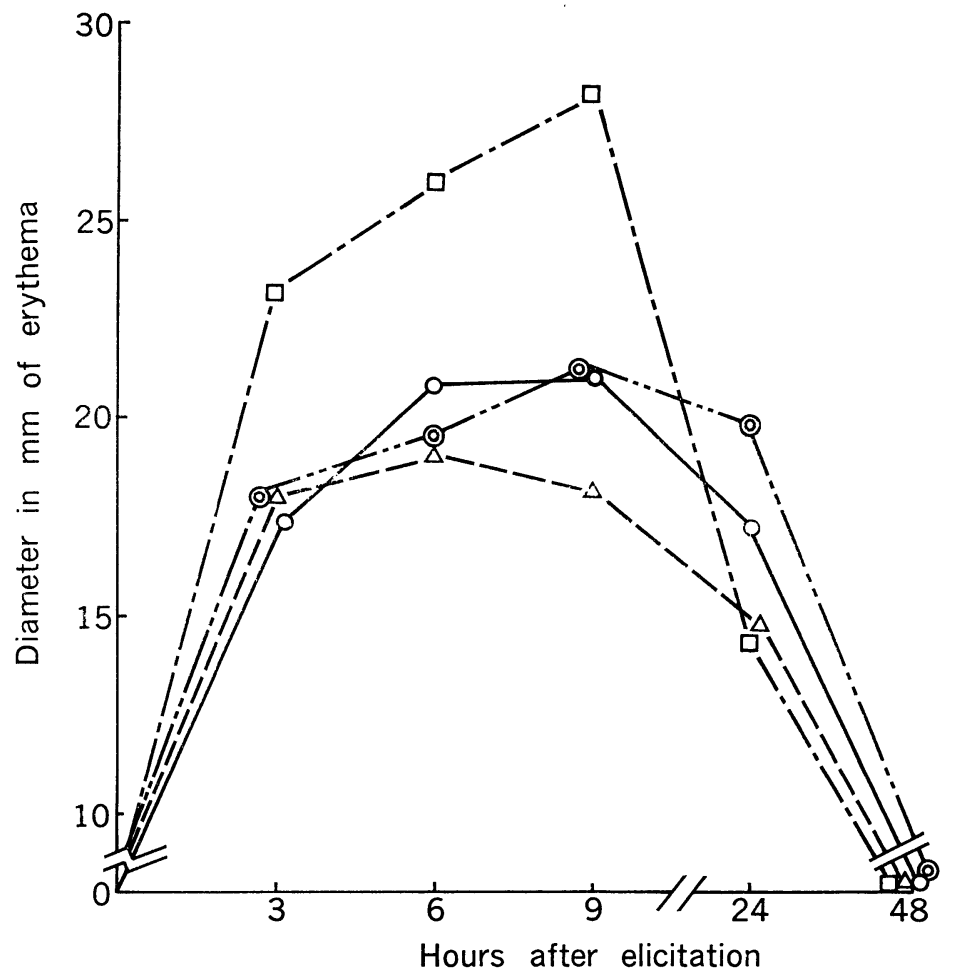

Fig. 5. Time course of skin reaction in rabbits.

The results obtained 12 weeks after sensitization are shown. Rabbits were sensitized by im injection of $0.5 \mathrm{ml}$ of each emulsion containing $1.25 \mathrm{mg}$ of $\mathrm{OA}$ and tested for skin reaction by id injection of $10 \mu \mathrm{g}$ of $\mathrm{OA}$ in $0.1 \mathrm{ml}$ saline. $-\mathrm{O}-\mathrm{W} / \mathrm{O} \mathrm{I}$; $-\longrightarrow \triangle--$, W/O II;

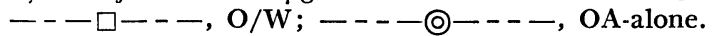




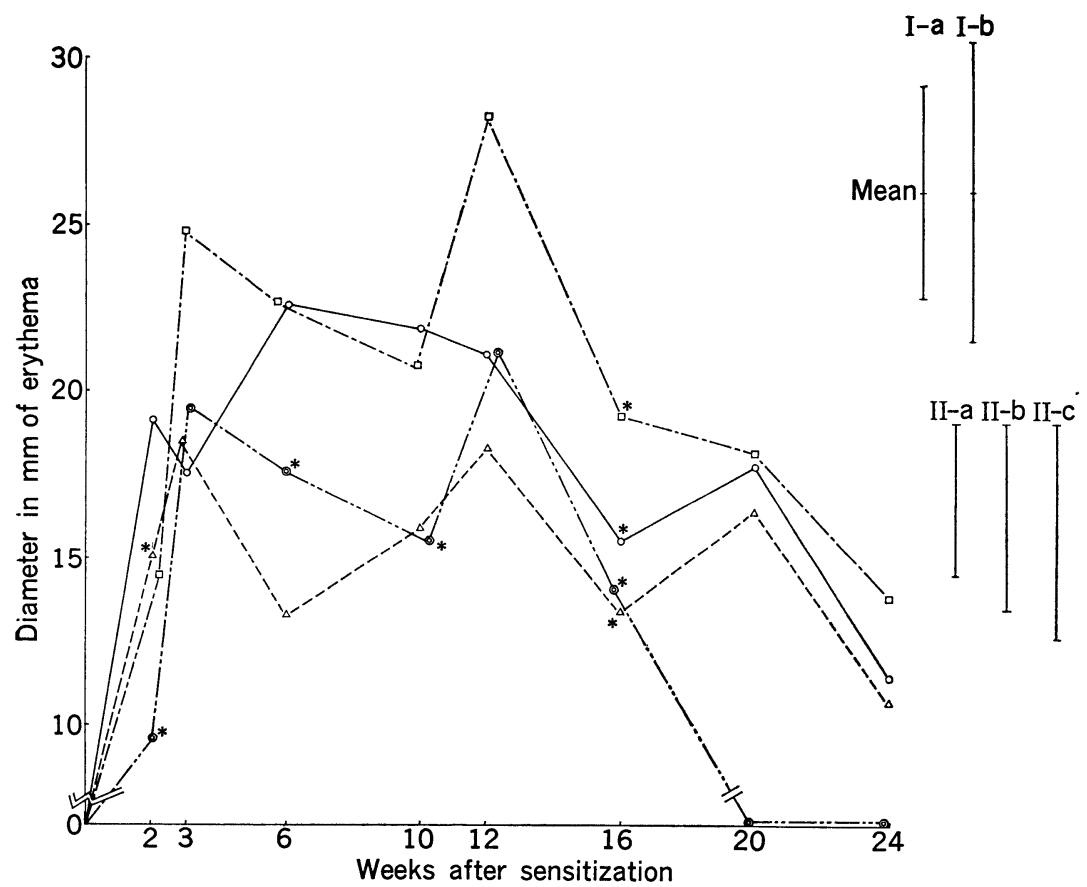

Fig. 6. Skin test in rabbits (9-hr reading).

Rabbits were sensitized by im injection of $0.5 \mathrm{ml}$ of each emulsion containing $1.25 \mathrm{mg}$ of $\mathrm{OA}$ and tested for skin reaction by id injection of $10 \mu \mathrm{g}$ of $\mathrm{OA}$ in $0.1 \mathrm{ml}$ saline at various intervals. For symbols see the legend to Fig. 5 .

* The reaction of only one rabbit was available for calculation of the mean.

Upper two vertical bars: Common confidence limits $(P=0.95)$ of the mean for the cases of two rabbits and one rabbit, were calculated to be 3.19 (I-a) and 4.51 (I-b), respectively. Lower three vertical bars: Sizes of difference, beyond which the difference between two mean values of erythema is significant $(\mathrm{P}=0.05)$ for the combinations of two and two rabbits (II-a), two and one rabbits (II-b) and one and one rabbits (II-c), were calculated to be $4.53,5.54$ and 6.40 , respectively.

\section{Skin Reactivity of Rabbits}

\section{Time course of skin reaction}

The erythema reaction to OA, accompanied by edema until about $6 \mathrm{hr}$ after injection, was only redness with somewhat vague edge but without significant induration. The time course of the reaction indicated an immediate type hypersensitivity as shown in Fig. 5, which reached a peak 6 to $9 \mathrm{hr}$ after injection and almost completely faded in $48 \mathrm{hr}$.

2. Kinetics of the skin reactivity

The reactivity of each rabbit was expressed in terms of the mean diameter of 7 erythemas $9 \mathrm{hr}$ after injection. The results are shown in Table III and Fig. 6. The values in Fig. 6 and Table III are each the mean of two rabbits; those with asterisks were each from one rabbit. A common variance was calcu- 
TABLE III

Skin test in rabbits (reading in $9 \mathrm{hr}$ )

\begin{tabular}{ccccc}
\hline \multirow{2}{*}{$\begin{array}{c}\text { Weeks afte } \\
\text { sensitization }\end{array}$} & \multicolumn{4}{c}{ Material } \\
\cline { 2 - 5 } & W/O I & W/O II & O/W & OA-alone \\
\hline 2 & $19.101)$ & $15.13^{*}$ & 14.45 & $9.56^{*}$ \\
& $(15.91-22.29)^{2)}$ & $(10.62-19.28)$ & $(11.26-17.64)$ & $(5.05-14.07)$ \\
3 & 17.50 & 18.45 & 24.75 & 19.50 \\
& $(14.31-20.69)$ & $(15.26-21.64)$ & $(21.56-27.94)$ & $(16.31-22.69)$ \\
6 & 22.55 & 13.25 & 22.70 & $17.57^{*}$ \\
& $(19.36-25.74)$ & $(10.06-16.44)$ & $(19.51-25.89)$ & $(13.06-22.08)$ \\
10 & 21.90 & 15.85 & 20.75 & $15.55 *$ \\
& $(18.71-25.09)$ & $(12.66-19.04)$ & $(17.56-23.94)$ & $(11.04-20.06)$ \\
12 & 21.05 & 18.25 & 28.15 & 21.15 \\
& $(17.86-24.24)$ & $(15.06-21.44)$ & $(24.96-31.34)$ & $(17.96-24.34)$ \\
16 & $15.52 *$ & $13.39 *$ & $19.17 *$ & $14.14 *$ \\
20 & $(11.01-20.03)$ & $(8.88-17.90)$ & $(14.66-23.68)$ & $(9.63-18.65)$ \\
24 & 17.70 & 16.35 & 18.10 & 0 \\
& $(14.51-20.89)$ & $(13.16-19.54)$ & $(14.91-21.29)$ & 0 \\
\hline
\end{tabular}

1) Mean diameter in $\mathrm{mm}$ of erythema, 2) $95 \%$ confidence limits, ${ }^{*}$ The reaction of only one rabbit for calculation of mean (for details see the text).

lated to be 4.74 from 22 variances obtained with 22 pairs of rabbits, for which deviations from variance homogeneity was not significant at a probability $(P=0.05)$. With the value of common variance thus obtained, common confidence limits $(\mathrm{P}=0.95)$ were calculated for the cases of two rabbits and one rabbit to be 3.19 and 4.51, respectively, as illustrated in the upper right corner of Fig. 6. For convenience of assessment, the size of difference, beyond which the difference between two mean values of erythema is significant at a probability $(\mathrm{P}=0.05)$ with 21 degrees of freedom, was also calculated for the combinations of two and two, two and one, and one and one rabbits to be 4.53, 5.54 and 6.40, respectively, as presented in the lower right corner of Fig. 6 .

From these statistical analyses, the followings may be deduced.

The reactivity of the $\mathrm{O} / \mathrm{W}$ type group was often higher than that of the OA-alone and also the W/O II type groups, and equivalent to or sometimes higher than that of the W/O I type group throughout the observation period. The peak was at week 12 in the $\mathrm{O} / \mathrm{W}$ type group. The reaction patterns of the other emulsion type groups showed some fluctuations. For further validation, it is necessary to use more animals. The reactivity of the OA-alone group was sometimes high, persisting slightly shorter than that of the adjuvant groups. The control skin section did not show any hyperreactivity.

3. Histopathological observations of the skin reaction

Histopathological findings of the erythema were not related to the emulsion types throughout the observation period. The early histopathological responses were perivascular infiltration of polymorphonuclear leukocytes (PMN), edema 
and capillary dilation. Few round cells (macrophage, lymphoid cells, etc.) were observed in $48 \mathrm{hr}$ after injection.

\section{Histopathological Changes at the Injection Site}

Main histopathological findings at the injection site in rabbits and mice are summarized in Tables IV and V, respectively. The OA-alone group showed only a little changes, if there were any, $72 \mathrm{hr}$ after injection.

1. Rabbits: In $72 \mathrm{hr}, \mathrm{PMN}$ and edema (including injected substances) were recognized and most PMN were degenerated with debris of nuclei. The exudative inflammatory lesion started to turn into typical abscesses at weeks 1 or 2. Abscess formation reached maximum in all type groups at week 2. Abscess was less extensive and less loose in the $\mathrm{W} / \mathrm{O} \mathrm{I}$ and $\mathrm{W} / \mathrm{O}$ III type groups than in the $\mathrm{W} / \mathrm{O}$ II and $\mathrm{O} / \mathrm{W}$ type ones. In most animals of the last group, abscesses formed were particularly extensive and inspissated (Fig. 8). All abscesses were bacteriologically sterile when tested on nutrient and blood agar plates. Degeneration of muscle fibers was observed with acute inflammatory exudates. Most of them were granular degeneration (Fig. 7). Lytic foci with or without oil droplets of various sizes were observed in the connective tissues and muscle layers after $72 \mathrm{hr}$ (Fig. 7). The cysts remained until the end of the observation period in all emulsion type groups, though they were minute in size and short-lasting in the $\mathrm{O} / \mathrm{W}$ type group.

Fibroplastic process of the lesions and macrophage proliferation with giant cells were observed around the cysts from 1 week. Macrophages and fibrocytes appeared to be intermingled with each other in the layer. The aggregates of epithelioid cell-like large mononuclear cells, lymphoid cells and plasma cells were found in the fibrocytes layer at weeks 1 or 2. The lymphoid cells formed lymphoid tissues around the cyst walls. In the W/O I type group, lymphoid tissue formation was extensive and germinal centers were found in some animals. The lymphoid tissue reaction in the W/O II type group was weaker than that in the W/O I type group, lacking in the germinal center. The W/O III type group exhibited diffuse infiltration of lymphoid cells, showing less aggregates. The lymphoid reaction in the $\mathrm{O} / \mathrm{W}$ type group was found only at weeks 2 and 8. The plasma cells observed in the W/O I and W/O II type groups were roughly the same in number, which was the greatest at week 8 . In the $\mathrm{O} / \mathrm{W}$ type group, infiltration of the cells was less intense in general and only at week 2 it attained a similar intensity to that of the W/O I type group. The W/O III type group did not show any plasma cell reaction.

Most abscess turned to organization by 4 weeks. Organization in the $\mathrm{O} / \mathrm{W}$ type group was particularly quick. The granulation tissues around gross cysts formed a thin layer, while a thick layer around minute cysts. In about 4 weeks, the granulation tissues gradually formed thin walls of collagen around the remaining cysts. Thus the granulation tissues continued collagen formation.

From week 2, aggregation of large mononuclear cells, being intensified and 
TABLE IV

Main histopathological findings at the injection site in rabbits

\begin{tabular}{|c|c|c|c|c|c|c|c|c|}
\hline \multirow{2}{*}{$\begin{array}{c}\text { Emulsion } \\
\text { type }\end{array}$} & \multirow{2}{*}{ finding } & \multicolumn{5}{|c|}{ Time after injection } & \multirow[b]{2}{*}{$16 \mathrm{w}$} & \multirow[b]{2}{*}{20} \\
\hline & & $72 \mathrm{hr}$ & $1 \mathrm{w}$ & $2 \mathrm{w}$ & $4 \mathrm{w}$ & $8 \mathrm{w}$ & & \\
\hline \multirow{3}{*}{ W/O I } & Abscess & - & - & $\pm \sim+$ & \pm & - & - & - \\
\hline & Granuloma & - & - & $-\sim \pm$ & + & $+\sim H^{*}$ & - & - \\
\hline & Lymphoid tissue & - & + & - & + & $\begin{array}{l}\mathrm{H} \sim \mathrm{H} \\
\mathrm{gc}+\end{array}$ & - & - \\
\hline \multirow{3}{*}{ W/O II } & Abscess & - & $+\sim H$ & $+\sim \mathrm{m}$ & - & - & - & - \\
\hline & Granuloma & - & $\mathrm{g}^{ \pm}+$ & $\pm \sim+$ & $\mathrm{g}^{+*}$ & $\mathrm{~g}^{+*}$ & - & - \\
\hline & Lymphoid tissue & - & + & $H \sim H$ & + & $H \sim H$ & - & - \\
\hline \multirow{3}{*}{ W/O III } & Abscess & $-\sim \pm$ & - & $\pm \sim+$ & - & - & - & - \\
\hline & Granuloma & - & $\mathrm{g}^{-}+$ & $\frac{-\sim \pm}{\mathrm{g}+}$ & $-\sim \pm$ & - & - & - \\
\hline & Lymphoid tissue & - & - & - & \pm & - & - & - \\
\hline \multirow{3}{*}{$\mathrm{O} / \mathrm{W}$} & Abscess & $\pm \sim+$ & $\pm \sim+$ & H & - & - & - & - \\
\hline & Granuloma & - & - & - & - & - & - & - \\
\hline & Lymphoid tissue & - & - & $+\sim+1$ & - & + & - & - \\
\hline
\end{tabular}

*: atypical granuloma, gc: with germinal center, g: giant cell.

TABLE V

Main histopathological findings at the injection site in mice

\begin{tabular}{|c|c|c|c|c|c|c|c|c|}
\hline \multirow{2}{*}{$\begin{array}{c}\text { Emulsion } \\
\text { type }\end{array}$} & \multirow{2}{*}{ finding } & \multicolumn{7}{|c|}{ Time after injection } \\
\hline & & $72 \mathrm{hr}$ & $1 \mathrm{w}$ & $2 \mathrm{w}$ & $4 \mathrm{w}$ & $8 \mathrm{w}$ & $16 \mathrm{w}$ & $20 \mathrm{w}$ \\
\hline \multirow{3}{*}{ W/O I } & Abscess & - & \pm & $\pm \sim+$ & \pm & - & - & - \\
\hline & Granuloma & - & - & $g^{+}+$ & $\mathrm{g}^{+}$ & $\begin{array}{c}+\sim+ \\
\mathrm{g} H\end{array}$ & $\mathrm{~g}_{+}^{+} \sim+$ & + \\
\hline & Lymphoid tissue & - & - & H & $\pm \sim+$ & $\stackrel{\mathrm{Ht}}{\mathrm{gc}}+$ & + & $H \sim H$ \\
\hline \multirow{3}{*}{ W/O II } & Abscess & \pm & \pm & $\pm \sim+$ & - & - & - & - \\
\hline & Granuloma & - & $\mathrm{g}-$ & $\mathrm{g}_{+}^{+}$ & $\mathrm{g}^{+}+$ & $\mathrm{g}^{+}+$ & $\mathrm{g}^{\mathrm{H}}+$ & $H \sim H$ \\
\hline & Lymphoid tissue & - & - & H & + & $\stackrel{+}{\mathrm{gc}}+$ & $H \sim H$ & $H \sim H$ \\
\hline \multirow{3}{*}{ W/O III } & Abscess & - & \pm & \pm & - & - & - & - \\
\hline & Granuloma & - & - & $\mathrm{g}^{ \pm}+$ & $\pm \sim+$ & $\frac{ \pm \sim+}{\mathrm{g}+}$ & $\mathrm{g}^{+}+$ & - \\
\hline & Lymphoid tissue & - & - & - & H & + & $H \sim H$ & $H \sim H$ \\
\hline \multirow{3}{*}{$\mathbf{O} / \mathrm{W}$} & Abscess & \pm & + & $\pm \sim+$ & - & - & - & - \\
\hline & Granuloma & - & - & \pm & $\frac{ \pm \sim+}{\mathrm{g}+}$ & $\pm \sim+$ & $\pm \sim+$ & \pm \\
\hline & Lymphoid tissue & - & - & $+\sim+$ & + & $\mathrm{gc}^{+}+$ & H & + \\
\hline
\end{tabular}

For symbols see the legend to Table IV. 


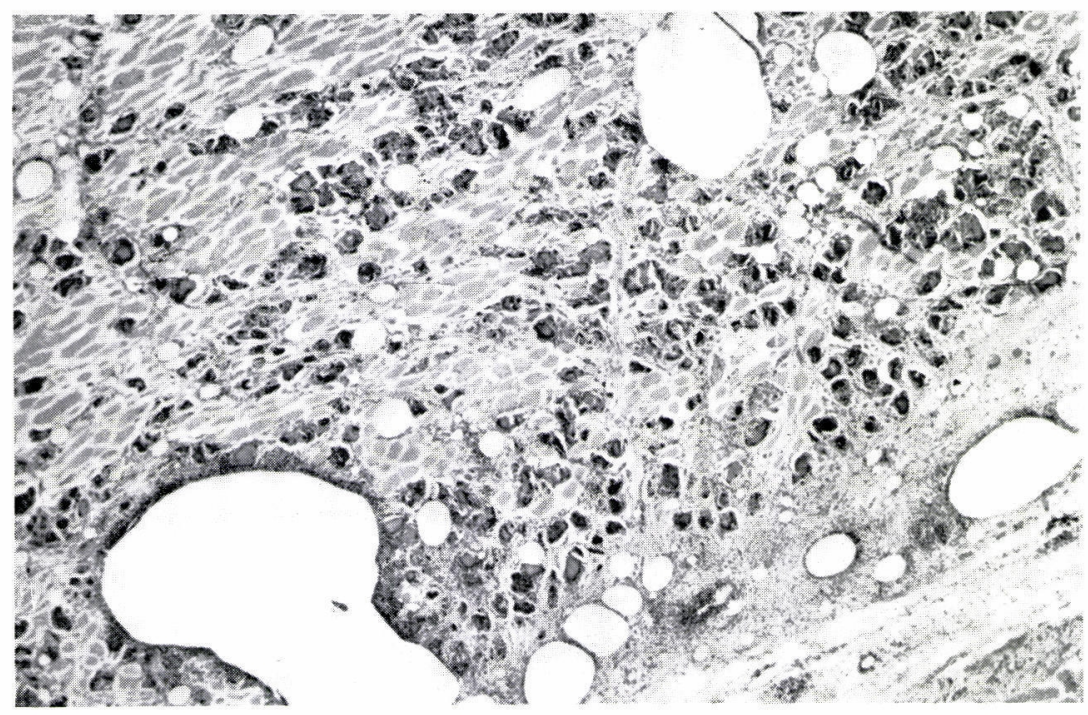

Fig. 7. W/O I group, rabbit, $2 \mathrm{w}$, injection site: Large and small cysts and numerous granular degeneration of muscle fibers. $\times 30, \mathrm{H}-\mathrm{E}$.

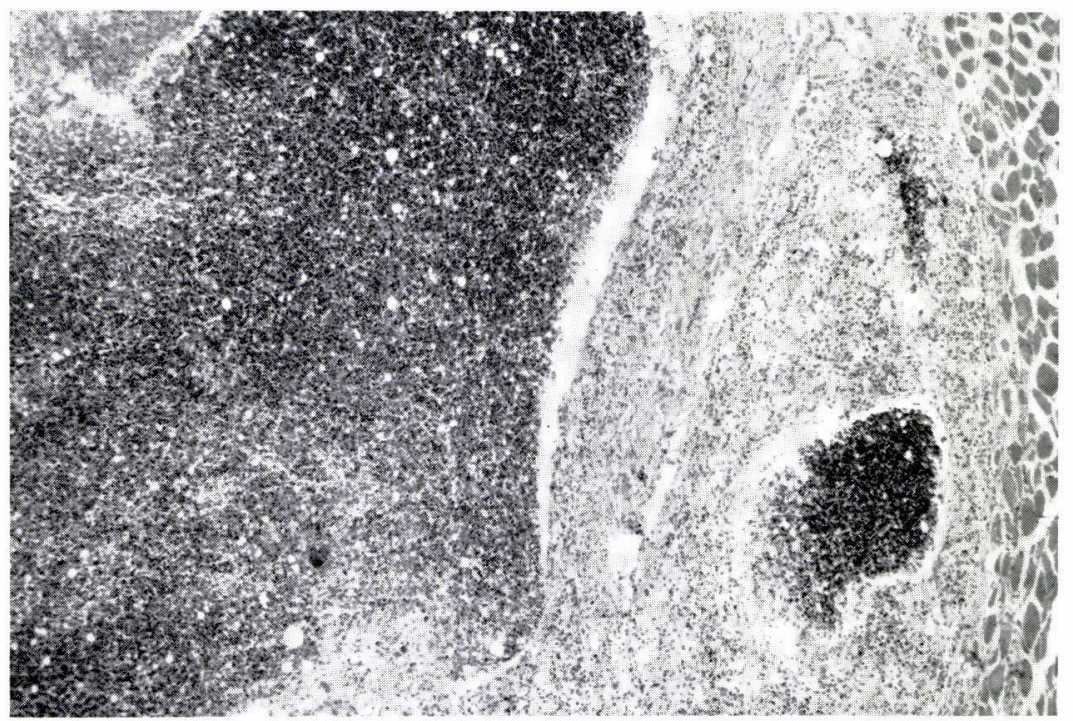

Fig. 8. $\mathrm{O} / \mathrm{W}$ group, rabbit, $2 \mathrm{w}$, injection site: Severe abscess formation $(+++)$ and granulation tissue. $\times 40, \mathrm{H}-\mathbf{E}$. 


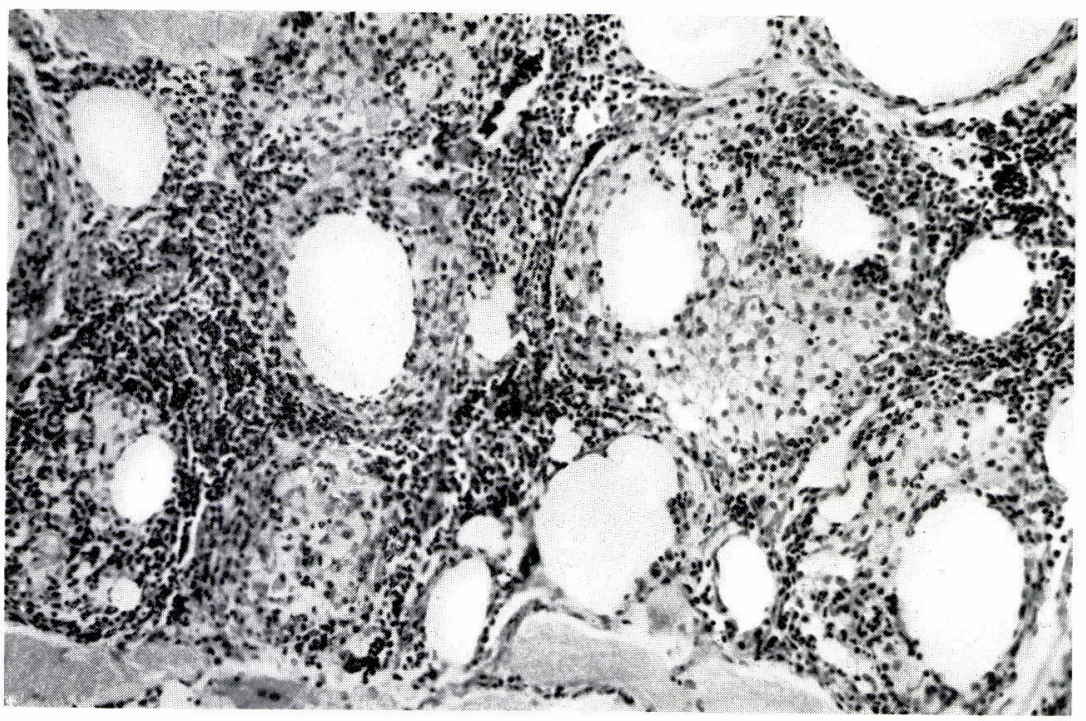

Fig. 9. W/O I group, rabbit, $8 \mathrm{w}$, injection site: Atypical granulomatous lesions consisting of cells with foamy cytoplasm and the lymphoid tissues around them. $\times 150, \mathrm{H}-\mathrm{E}$.

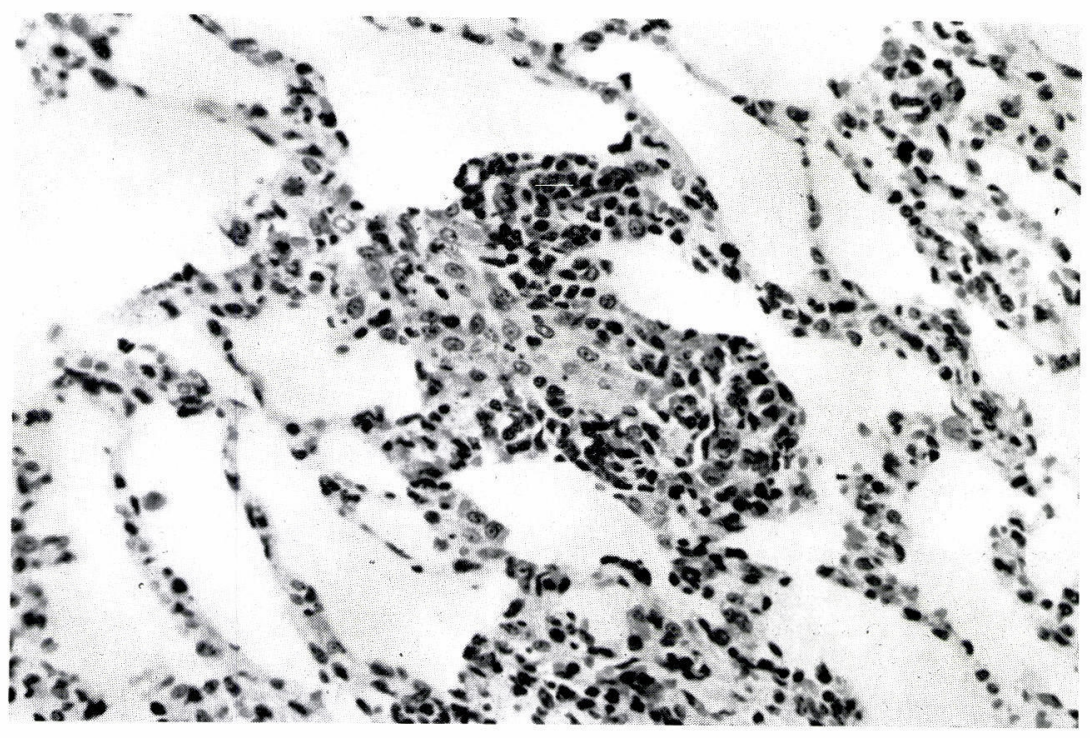

Fig. 10. W/O II group, rabbit, $2 \mathrm{w}$, lungs: Micro granulomatous lesion in the alveolar wall. $\times 300$, H-E.

developing granulomatous tissue associated with giant cells, appeared. Some lesions of typical granuloma, found in FIA-injected animals (Kurokawa et al., 1967; White and Herbert, 1975), were rarely observed in 2 or 4 weeks. However, 


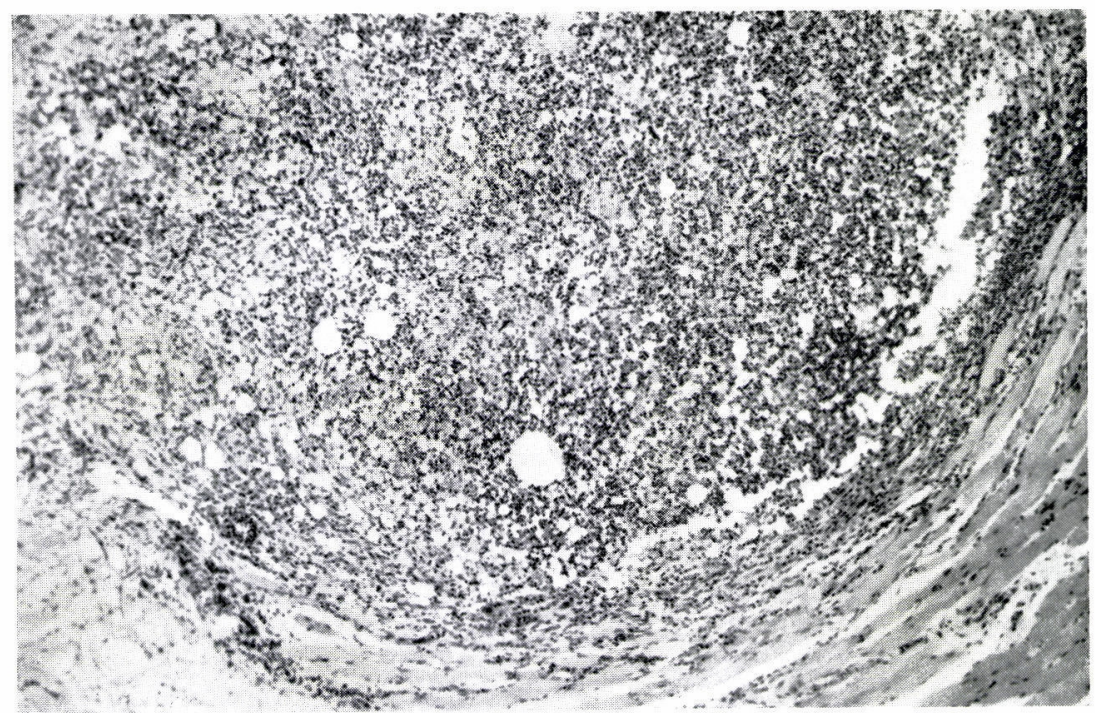

Fig. 11. $\mathrm{O} / \mathrm{W}$ group, mouse, l $\mathrm{w}$, injection site: The severest abscess formation $(+)$ in mice. $\times 75, \mathrm{H}-\mathrm{E}$.

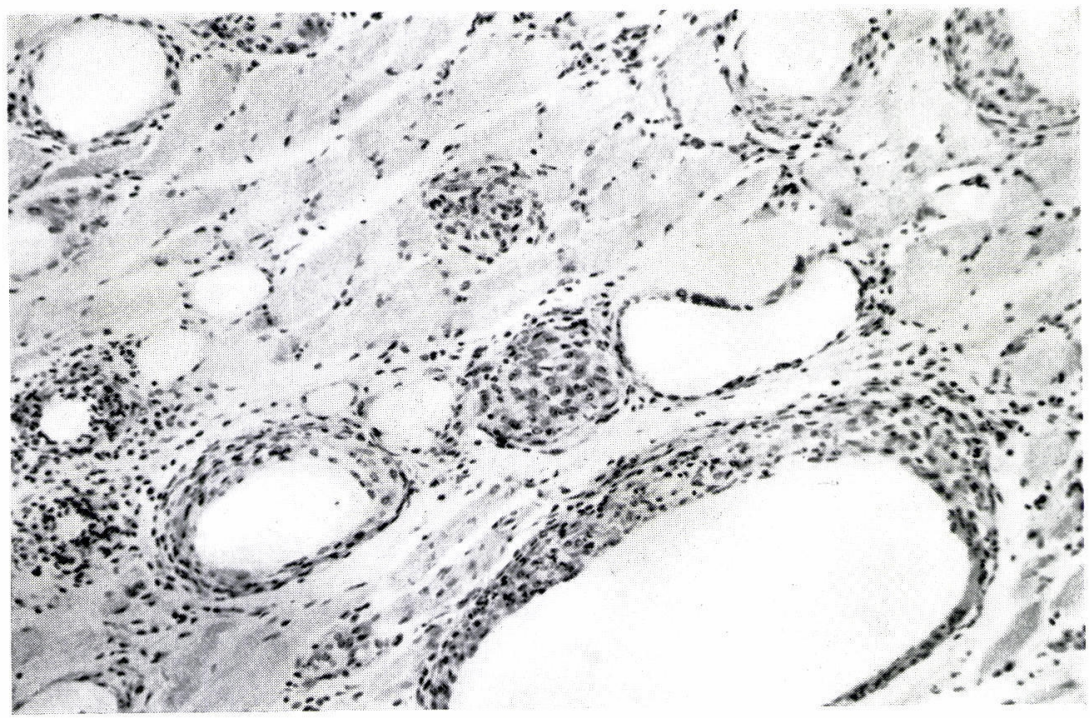

Fig. 12. W/O II group, mouse, $2 \mathrm{w}$, injection site: Granulomatous proliferation of macro phages including epithelioid cells around oil droplets. $\times 150, \mathrm{H}-\mathrm{E}$.

most granulomatous lesions were atypical in 4 weeks. In many cases granuloma indicated two types of reactions; one consisting of large mononuclear cells, whose cytoplasm was stained deeply with eosin, and the other consisting of aggregates 


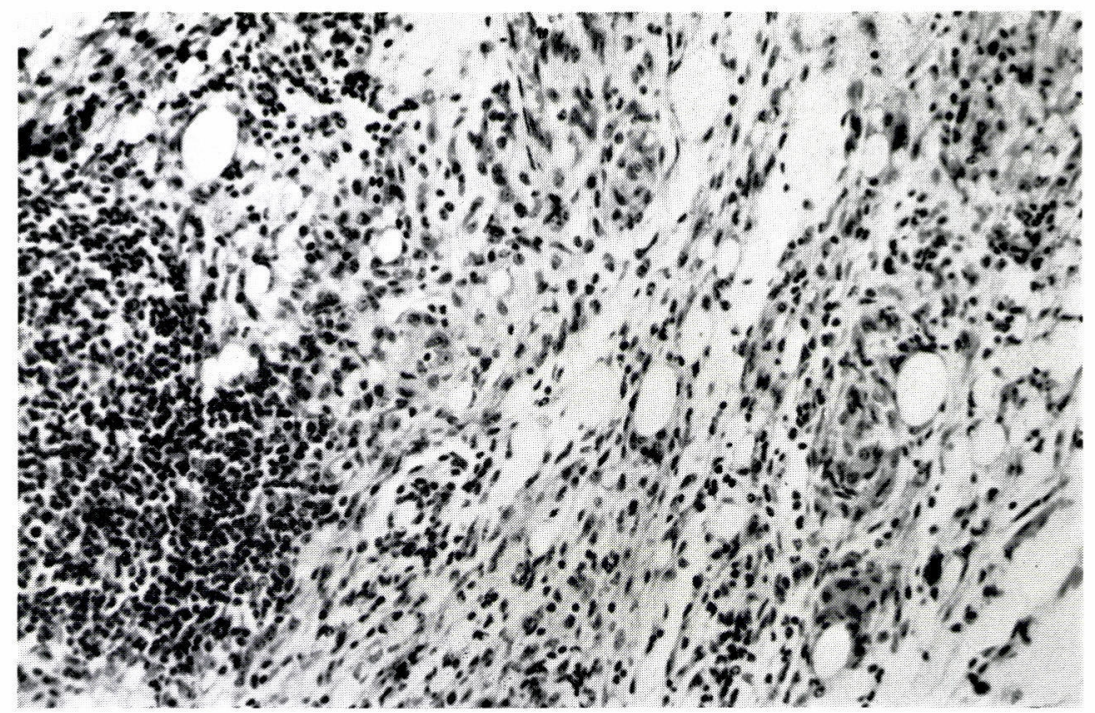

Fig. 13. $\mathrm{O} / \mathrm{W}$ group, mouse, $8 \mathrm{w}$, injection site: Slight granulomatous lesions around minute cysts, being maximal in this group, and well-formed lymphoid tissue (left). $\times 200$, H-E.

of macrophage-type cells, whose foamy cytoplasm was lightly stained with eosin (Fig. 9). Granuloma was seen nearly to the same extent in the W/O I and $\mathrm{W} / \mathrm{O}$ II type groups, uncertain in the W/O III type group, and absent in the $\mathrm{O} / \mathrm{W}$ type group. Most cellular reactions ceased by 16 to 20 weeks (Table IV).

In summary, adjuvant-injected into the muscles induced cyst formation, which caused a series of reactions irrespective of the type of emulsion, i.e. suppurative inflammation forming abscess and productive inflammation as a result of reparation process.

2. Mice: The main histopathological findings in mice were similar to those in rabbits. Abscesses in mice appeared as early as in $72 \mathrm{hr}$, though less extensive than those in rabbits. They were atypical and in most cases resembling aseptic suppurations. The $\mathrm{O} / \mathrm{W}$ type group alone showed typical abscess formation at week 1 (Fig. 11). At week 2 or later, the lymphoid cells with plasma cells increased in number within the granulation tissues around cysts. In 4 weeks, began to appear the concentrated lymphoid cell lesions, consisting of only small lymphocytes and closely resembling to lymph follicle. The W/O I type group exhibited well-developed lymphoid tissue at week 8 (Fig. 14). Except the W/O III type group, all type groups showed germinal centers at week 8 .

The granulomatous reactions accompanied by giant cells were different from those in rabbits. Granulomata in mice were typical solid proliferation of epithelioid cells around oil droplets (Fig. 12). Gross cysts, remained intact. Granuloma was most extensive at week 4 in the W/O I type group and at week 16 in the W/O II type group; it persisted till the 20th week. The W/O III 


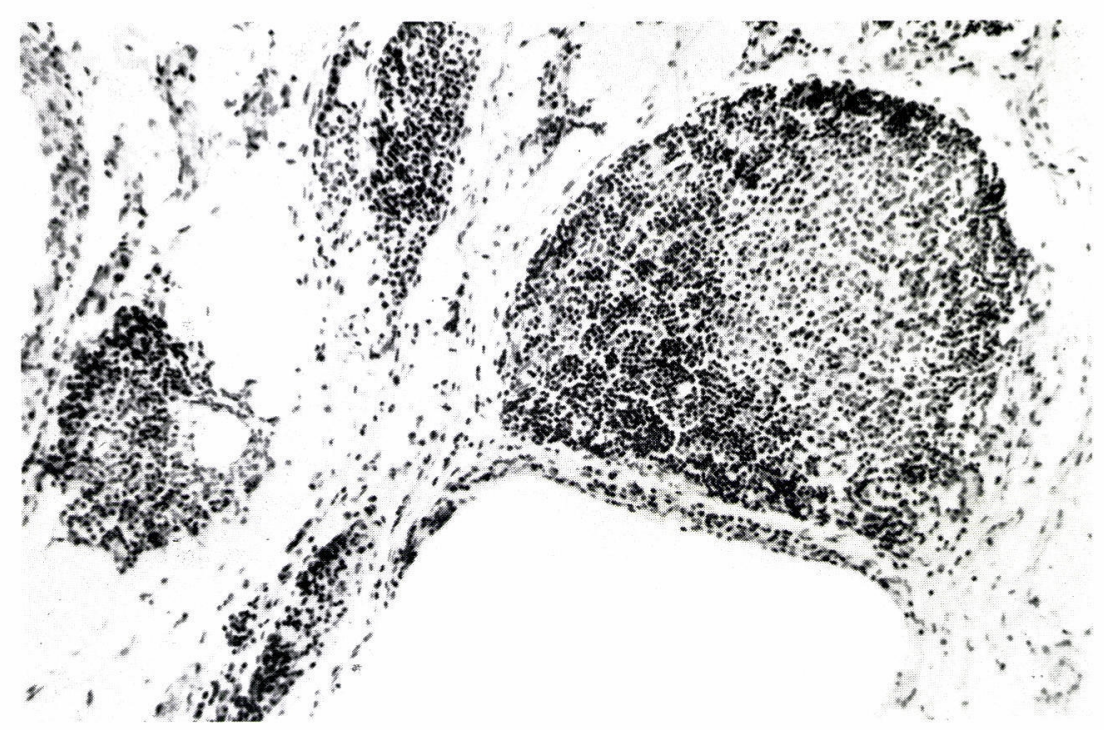

Fig. 14. W/O I group, mouse, $8 \mathrm{w}$, injection site: The well-developed lymphoid tissue having germinal center near a cyst. $\times \mathbf{1 5 0}$, H-E.

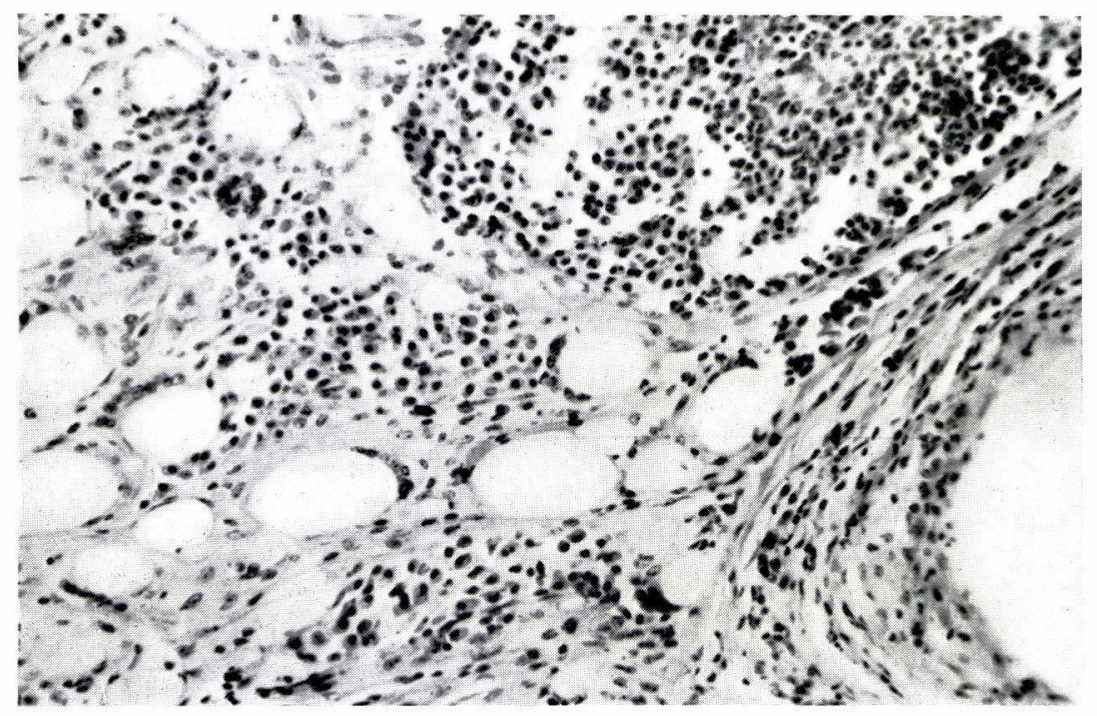

Fig. 15. W/O II group, mouse, $8 \mathrm{w}$, injection site: Massive infiltration of plasma cells around a cyst. $\times 200, \mathrm{H}-\mathrm{E}$.

type group showed incomplete or immature granuloma formation between 4 and 16 weeks. The $\mathrm{O} / \mathrm{W}$ type group displayed even milder lesions than did the $\mathrm{W} / \mathrm{O}$ III type group between 4 and 16 weeks (Fig. 13). The plasma cells formed 
intensive aggregates around cyst walls (Fig. 15), and some massive infiltration of plasma cells contained Russell bodies. The plasma-cell lesions increased in number at week 4 or later, clearly recognizable at week 20 in the W/O I and W/O II type groups. The plasma cells weakly infiltrated in the $\mathrm{W} / \mathrm{O}$ III and $\mathrm{O} / \mathrm{W}$ type. groups. Granulation and lymphoid tissues were observable for a longer period in mice than in rabbits and remained considerably extensive even 20 weeks. after injection (Table V).

\section{Histopathological Changes of Main Visceral Organs}

\section{Rabbits}

Lungs: Granulomatous lesions were found in the alveolar wall in the W/O II type group at weeks 2 and 8 (Fig. 10). The peribronchial and peribronchiolar lymphoid tissues enlarged except for the $\mathrm{O} / \mathrm{W}$ type group, and some of them, particularly those in the W/O II type group, had germinal centers. Hypertrophy of the lymphoid tissue and appearance of the macrophage type. cells were rare in the OA-alone group.

Liver: A granulomatous lesion in the periportal vein was observed in the W/O I type group at week 1 .

2. Mice

Lungs: No typical granulomatous lesion was observed in the lung. The peribronchial, hilar and mediastinal lymphoid tissues showed moderate to marked swelling. Some of them contained germinal centers and showed hypertrophy at various times. The lungs of the $\mathrm{O} / \mathrm{W}$ type and the OA-alone groups were enlarged at an early stage, while activation in the W/O I type group was much later.

Liver: Granulomatous lesions containing few neutrophils were found in all except the OA-alone group.

In either animal species, there were no histopathological findings attributable to a particular emulsion type in other visceral organs than the above described ones.

\section{Histopathological Comparison between CSI and Difco Adjuvants}

Difco adjuvants were used as control of CSI adjuvants. There seemed to be some quantitative differences in histopathological changes at the injection site between the two adjuvants.

Abscess formation: The reactions of the CSI adjuvant groups were weaker than those of the Difco adjuvant groups. The $\mathrm{O} / \mathrm{W}$ type group of Difco adjuvant showed abscess formation in $72 \mathrm{hr}$, when the other type groups of Difco adjuvant exhibited no abscess. At week 1, when abscess was most extensive, there was not much difference in the intensity of abscess formation among the emulsion type groups of Difco adjuvant. 
Granuloma: CSI adjuvant induced slightly more extensive granulomatous lesions in the W/O III and $\mathrm{O} / \mathrm{W}$ type groups than in the corresponding type groups of Difco adjuvant.

Histopathological changes of the main visceral organs did not show much difference between the two adjuvants.

\section{FFA Contents and Composition of Arlacel $A$ and CSI Adjuvant}

FFA contents of each emulsion type of adjuvant were determined as shown in Table VI. The FFA contents of the W/O types were $5.2(\mathrm{~W} / \mathrm{O}$ II) and 5.6 (W/O III) times higher than that of the $\mathrm{O} / \mathrm{W}$ type emulsion. The amounts of

\section{TABLE VI}

Relation between FFA content of each material and abscess formation

\begin{tabular}{|c|c|c|c|c|c|}
\hline \multirow{2}{*}{ Material } & \multirow{2}{*}{\multicolumn{2}{|c|}{$\frac{\text { FFA }}{(\mu \text { moles } / 0.1 \mathrm{ml})}$}} & \multirow{2}{*}{$\begin{array}{l}\text { Oleic acid4) } \\
(\mathrm{mg} / 0.1 \mathrm{ml})\end{array}$} & \multicolumn{2}{|c|}{ Abscess formation $\left.{ }^{5}\right)$} \\
\hline & & & & Rabbit & Mouse \\
\hline Adjuvant ${ }^{1)}$ & $2.450^{2)}$ & $(2.062-2.838)^{3)}$ & $0.692(0.653-0.731)$ & $\mathrm{ND}^{6)}$ & ND \\
\hline W/O I & 1.200 & (1.117-1.283) & $0.339(0.317-0.361)$ & $\pm \sim+$ & $\pm \sim+$ \\
\hline W/O II & 1.170 & (1. 142-1.198) & $0.330 \quad(0.322-0.338)$ & $+\sim \#$ & $\pm \sim+$ \\
\hline W/O III & 1.260 & (1.204-1.316) & $0.356(0.339-0.373)$ & $\pm \sim+$ & \pm \\
\hline $\mathrm{O} / \mathrm{W}$ & 0.227 & $(0.199-0.255)$ & $0.064(0.056-0.072)$ & W & + \\
\hline OA-alone & 0.020 & $(0.014-0.026)$ & $0.006(0.004-0.008)$ & - & - \\
\hline
\end{tabular}

1) The original adjuvant consists of 9 parts of Drakeol and 1 part of Arlacel $A$,

2) Mean, 3) $95 \%$ confidence limits of the mean, 4) Expressed as mg equivalent of oleic acid, 5) Indicated by maximum changes throughout the experiments, ${ }^{6}$ Not done.

TABLE VII

Composition of FFA in Arlacel $A$ and CSI adjuvant

\begin{tabular}{crc}
\hline Fatty acid & $\begin{array}{c}\text { Arlacel A } \\
(\%)\end{array}$ & $\begin{array}{c}\text { Adjuvant* } \\
(\%)\end{array}$ \\
\hline $14: 0 * *$ & 2.3 & 2.8 \\
$15: 0$ & 2.3 & 1.9 \\
$16: 0$ & 5.0 & 5.8 \\
$16: 1$ & 10.1 & 8.8 \\
$17: 1$ & 1.2 & 1.0 \\
$18: 0$ & 0.6 & 1.4 \\
$18: 1$ & 65.8 & 67.3 \\
$18: 2$ & 3.6 & 4.2 \\
$18: 3$ & 3.6 & 1.3 \\
Others & 5.4 & 5.5 \\
Total & 99.9 & 100.0 \\
\hline
\end{tabular}

* Consists of 9 parts of Drakeol and 1 part of Arlacel A.

** Number of carbon. 
FFA in CSI adjuvant were $3.2(\mathrm{O} / \mathrm{W})$ and $6.6(\mathrm{~W} / \mathrm{O} \mathrm{II})$ times larger than that in Difco adjuvant (not presented in the table). Table VII shows the FFA composition of Arlacel A and CSI adjuvant analyzed by gas-liquid chromatography. The main FFA was oleic acid $\left(\mathrm{C}_{18: 1}\right)$. The Drakeol preparation contained no detectable FFA.

\section{Discussion}

To study basically the mineral oil adjuvants, rabbits and mice were intramuscularly injected with each of several types of emulsions, which were extremely different in some physical properties. Precipitin antibody titer and skin reactivity to $\mathrm{OA}$ and histopathological changes on the injected site and the main visceral organs were examined periodically for 20,24 or 28 weeks.

\section{Precipitin formation and skin hyperreactivity}

The effects of adjuvant on formation of precipitin to OA were more fluctuate with time in rabbits than in mice, though there was not much difference in the precipitin titer among animal species without adjuvant. The response of the rabbit seemed to vary to a certain extent depending upon the physical properties of emulsion. The mouse differed from the rabbit in that the emulsion type did not induce remarkable effects on the response pattern.

It is believed that $O / W$ type adjuvant is generally poor in the adjuvant action as compared with W/O type one. Freund et al. (1948), comparing agglutinin titers in the rabbits subcutaneously injected with $\mathrm{S}$. typhi-W/O- or $-\mathrm{O} / \mathrm{W}$ type-adjuvant vaccine, reported that $\mathrm{O} / \mathrm{W}$ type was unsatisfactory even in the presence of paraffin oil. He speculated that such emulsion was ineffective because of rapid dispersion from the injection site. Woodhour, Jensen and Warren (1961) studied the effect of the two emulsion types (W/O and $\mathrm{O} / \mathrm{W}$ ) on hemagglutination-inhibition antibody in the guinea pigs injected intramuscularly with influenza polyvalent vaccines. Herbert (1968) investigated the effect of $\mathrm{O} / \mathrm{W}$ adjuvant on passive hemagglutinin antibody to subcutaneously injected $\mathrm{OA}$ in mice. They also concluded that the effect of the $\mathrm{O} / \mathrm{W}$ type on antibody formation was generally poor and short lasting as compared with $\mathrm{W} / \mathrm{O}$ type emulsion. As the experimental conditions were different from each other in various points, direct comparison of the present results with theirs is difficult.

The $\mathrm{O} / \mathrm{W}$ type, however, employed in the present experiments was found to be often equivalent or sometimes rather superior to the W/O I type in enhancing precipitin production to $\mathrm{OA}$ in rabbits and mice, in terms of both titers and duration of immune responses. The results confirm those obtained with guinea pigs (Goto et al., 1972, 1974a). Besides O/W type adjuvant showed an enhancing effect on immediate-type hypersensitivity of the rabbit skin to OA, while the effects of $\mathrm{W} / \mathrm{O}$ type adjuvants on the skin reactivity were only vague. 
These results are also consistent with that with guinea pigs (Goto et al., 1972, 1974a; unpublished data).

That these rather unexpected results were not due to any particular properties of CSI adjuvant was evidenced by the experiment using Difco adjuvant, which is widely used in the field of immunology.

In the experiment with CSI adjuvant in mice, the precipitin titer increased slowly but continued longer in the $\mathrm{O} / \mathrm{W}$ type group than in the other type groups. The precipitin level of the $\mathrm{O} / \mathrm{W}$ type group was lower at the first half of the observation period, but rather higher at the latter half than those of the other type groups (Fig. 3). The results indicate that such data, obtained under certain experimental conditions and within a relatively short period, might lead to a conclusion that the $\mathrm{O} / \mathrm{W}$ type is inferior to the $\mathrm{W} / \mathrm{O}$ type in the immune response-enhancing capacity.

The imperfect emulsion (W/O II) induced higher precipitin titers than did the perfect emulsion (W/O I) in rabbits at some points of observation. Therefore, the enhancement of antibody formation may not absolutely be poor with the W/O II type in mice or rabbits. That is, it is not always an absolute requirement that an oil adjuvant should be perfectly emulsified.

\section{Relationship between histopathological changes of the injection site and antibody production}

\section{1) Granuloma}

Snyder et al. (1966) reported chronic granuloma at the injection site of intramuscular injection of a typhoid adjuvant vaccine in a child. Granuloma was also found in the injection site and lungs of rabbits injected intramuscularly with influenza adjuvant vaccines (Kurokawa et al., 1967). The present experiment disclosed that granulomatous reaction of rabbits at the injection site was. primarily atypical. Most mice reacted with typical FIA granuloma, which was more extensive in mice than in guinea pigs. The W/O III (oil control) type induced virtually no granulomatous reaction. In view of these findings and of the appearance time of the reactions, it is likely that the immunological responses participated in the granulomatous reactions. Askonas and Humphrey (1958) reported that rabbits immunized by im injection of OA in FCA synthesized most of their antibody in the local granuloma. In the present experiments, the granuloma formation with the $\mathrm{O} / \mathrm{W}$ type was absent in rabbits and extremely weak in mice, though the precipitin antibody formation and immediate-type hypersensitivity of the $\mathrm{O} / \mathrm{W}$ type group were by no means inferior to the other type groups. Therefore, it is unlikely that the persistence of granuloma at the injection site is an important factor in antibody production.

2) Lymphoid tissue formation

Lymphoid tissue formation at the injection site was more vigorous in mice than in rabbits, and some mice formed germinal centers. Germinal centers were numerous particularly in the W/O I type group, in which the time of the 
highest precipitin titers coincided with that of the highest lymphoid tissue formation. There might be some relationship between the precipitin antibody formation and the lymphoid tissue formation in the $\mathrm{O} / \mathrm{W}$ type group in rabbits and mice.

3) Plasma cell reaction

In both animal species, the plasma cell reaction at the injection site was severe in the $\mathrm{W} / \mathrm{O}$ type groups, while none in the $\mathrm{W} / \mathrm{O}$ III type group in rabbits and mild in mice between 2 and 8 weeks after injection. The time precipitin titer were increasing coincided with that of strong plasma cell infiltration in mice of the $\mathrm{W} / \mathrm{O} \mathrm{I}$ and $\mathrm{W} / \mathrm{O}$ II type groups. In the $\mathrm{O} / \mathrm{W}$ type group, the reaction was also observed for a longer period, though mild, in mice than in rabbits. In this type group plasma cell infiltration was found only at the time of the highest precipitin titer in rabbits. These observations suggest that some immunological mechanisms play the main role in the plasma cell reaction.

Immunological implication of immediate type hypersensitivity to the observed histopathological changes was not clear.

\section{Histopathological changes of main visceral organs possibly related to oil emulsion types}

There have been few reports on the histopathological changes of main visceral organs in response to FIA. Laufer, Tal and Behar (1959) reported that granulomatous lesions were found in the liver and spleen of mice, in the lungs of guinea pigs, and in the lungs, brain and liver of hamsters injected with an oil-saline mixture by the sc route. Steiner, Langer and Schatz (1960) observed disseminated granulomatous lesions in the lungs, the liver and the kidneys of rabbits injected by the id route with Arlacel A or Bayol F in saline solution or a mixture of Arlacel A, Bayol F and saline solution. The purpose of their experiment was not the histopathological examination for harmful effects of FIA.

In the present experiments, granulomatous lesions were found in the lungs of rabbits 2 and 8 weeks after injection of the W/O II type, suggesting that the $\mathrm{W} / \mathrm{O}$ II type might move from the injection site to the lungs. The relation between histopathological changes of some other visceral organs and the type of emulsion was not clear in rabbits. In mice, granulomatous lesions in the lungs were not distinct and weaker than those in guinea pigs, and rare in the liver. It was not clear whether or not the type of emulsions played any role.

\section{Abscess formation at the injection site}

Abscess formation due to oil adjuvant is one of the important problems to be solved, since abscess formation at a relatively high rate has often been re- 
ported in humans following inoculation with some vaccines with mineral oil adjuvant (influenza vaccine: Henle and Henle, 1945; tetanus toxoid: MacLennan et al., 1965; cholera vaccine: Philippines Cholera Committee, 1965; Ogonuki et al., 1967).

\section{1) Relationship between stability of emulsion and abscess formation}

MacLennan et al. (1965) suggested possible relationship between the stability of emulsion and the local toxic effects. In rabbits, typical mineral oil abscess was severer with incompletely emulsified W/O II type emulsion and the $\mathrm{O} / \mathrm{W}$ type emulsion than completely emulsified W/O I and W/O III type emulsions. $\mathrm{O} / \mathrm{W}$ type emulsion caused remarkable abscess at the injection site in rabbits. It was observed also in mice that $\mathrm{O} / \mathrm{W}$ type emulsion was stronger in abscess formation.

TABLE VIII*

Relation between macroscopic abscess formation and FFA content of each biological product with FIA for human use

\begin{tabular}{lccc}
\hline Biological product & $\begin{array}{c}\text { Abscess } \\
\text { formation }\end{array}$ & $\begin{array}{c}\text { FFA } \\
(\mu \text { moles/0.1 ml })\end{array}$ & $\begin{array}{c}\text { Oleic acid** } \\
(\mathrm{mg} / 0.1 \mathrm{ml})\end{array}$ \\
\hline Tetanus toxoid $\left(\mathrm{B}_{1}\right)$ & - & 0.332 & 0.094 \\
Tetanus toxoid $\left(\mathrm{B}_{2}\right)$ & + & 0.712 & 0.202 \\
Cholera vaccine & + & 1.200 & 0.340 \\
Typhoid vaccine & + & 0.940 & 0.264 \\
\hline
\end{tabular}

* This table was composed from data of Hardegree and Pittman (1967).

** See the legend to Table VI.

2) Relationship between FFA content and abscess formation

Hardegree and Pittman (1967) demonstrated that a considerable amount of FFA was contained in such vaccine preparations that inducing abscess at a relatively high rate and that FFA was released from Arlacel A under certain conditions. They suggested that abscess formation with those vaccines might be attributable to FFA released in the preparation. Watanabe (1959) reported that abscesses were formed with relatively small amount of fatty acids of long chain carbons above $\mathrm{C}_{16}$ mainly in guinea pigs. The main fatty acid in Arlacel $A$ was oleic acid $\left(\mathrm{C}_{18: 1}\right)$ (Table VII). Berlin (1963) suggested that the unbound oleic acid may be the major toxic component in a toxic Arlacel A preparation. As shown in Table VI, however, no relation was shown between the amount of FFA and abscess formation. Since Hardegree and Pittman (1967) interpreted that the abscess formation is based on macroscopic observation, it is difficult to compare our data with theirs. It is improbable that FFA itself is the direct cause of abscess formation. Rather, it is likely that abscess formation depends on not only animal species but also the physical properties of emulsion. An extremely low viscosity, milky state, of the $\mathrm{O} / \mathrm{W}$ type may enable the emulsion to enter easily narrow spaces among muscle fibers and to form copious minute oil cysts subsequently promoting infiltration. This may explain the fact that the $\mathrm{O} / \mathrm{W}$ type induced severer abscess than other types despite its low ratio of 
oil content. Watanabe (1959) observed that guinea pigs developed weak leukocytic reactions. Kuratsuka (1970) reported that intradermal abscess formation with oleic acid was more intense in rabbits than in guinea pigs. According to Table VIII, constructed from the data (Table I) of Hardegree and Pittman (1967), abscess was formed in man with about $0.7 \mu$ moles $/ 0.1 \mathrm{ml}$ of FFA but not with about $0.3 \mu$ moles $/ 0.1 \mathrm{ml}$. The present experiment proved abscess formation in mice receiving CSI adjuvant with FFA content of about $1.2 \mu$ moles $/ 0.1 \mathrm{ml}$ in the $\mathrm{W} / \mathrm{O}$ II type and $0.2 \mu$ moles $/ 0.1 \mathrm{ml}$ in the $\mathrm{O} / \mathrm{W}$ type. (Table VI).

Abscess formation was severer in rabbits than in mice. This might be attributable to the fact that rabbits were given with five times as much adjuvant as mice. This is not true from the results of an experiment in which each of three rabbits was given $0.1 \mathrm{ml}$ of emulsion and abscess formation was to the same extent as in the rabbits injected with $0.5 \mathrm{ml}$ (unpublished data). The $\mathrm{O} / \mathrm{W}$ type group again formed most remarkable typical abscess.

In the present experimental system using Drakeol, the results mentioned just above indicate that the rabbit is an appropriate animal to detect abscess. formation. Mice are less suitable and guinea pigs the least. On the other hand, mice are suited for detection of granuloma formation in the injection site.

$\mathrm{O} / \mathrm{W}$ type emulsion used in the present experiments displayed the following characteristics. Abscess formation in this type group was more intense at its peak but organization was sooner than other type groups. Granulomatous lesion was extremely slight and incomplete in mice, and none in rabbits. In addition, most cysts were minute, that is, this type of adjuvant was easily removable probably by phagocytosis by macrophages. The lymphoid tissues were relatively well formed and long-lasting in mice. However, no specific histopathological change of main visceral organs was related to this type in any three animal species. The precipitin formation in this type group was equivalent or superior to that in the $\mathrm{W} / \mathrm{O}$ type groups in the titer and the duration. The $\mathrm{O} / \mathrm{W}$ type often induced significantly stronger skin reactivity than did the $\mathrm{W} / \mathrm{O}$ types.

These results have been confirmed by other experiments performed in the same way. Further studies on the effects of various emulsion types are in progress. in this laboratory.

\section{ACKNOWLEDGEMENTS}

The author wishes to express his gratitude to Dr. M. Kurokawa, Director, and Dr. K. Kuratsuka of the Department of General Biologics Control, the National Institute of Health, Tokyo, for their valuable advice and encouragement throughout the present work. The author is indebted also to Dr. T. Shimizu of the Department of Biomedical Research on Foods, the National Institute of Health, Tokyo, for his continuing guidance and helpful discussion about the histopathological observations, to Dr. S. Ishida of this Department for his advice about the statistical analysis, to Miss M. Amagai of this Department for her help in determination of free fatty acid, and to Mr. T. Tsurumizu of Chiba Serum Institute, Ichikawa, Chiba prefecture, for the supply of the adjuvant material. Thanks are also due to Mr. Y. Shimazaki and Mr. I. Funasaka for their technical help. 


\section{REFERENCES}

Askonas, B. A. AND Humphrey, J. H. (1958): Formation of specific antibodies and $\gamma$-globulin in vitro. A study of the synthetic ability of various tissues from rabbits immunized by different methods. Biochem. J., 68, 252-261.

Berlin, B. S. (1960): Gross physical properties of emulsified influenza virus vaccines and the adjuvant response. J. Immunol., 85, 81-89.

Berlin, B. S. (1963): Chemical and biologic properties of Arlacel A. Ann. Allergy, 21, 82-90.

Carter, R. L., Jamison, D. G. and Vollum, R. L. (1968): Histological changes evoked in mice by Freund's incomplete adjuvant. J. Pathol. Bacteriol., 95, 471-476.

Committee on Influenza and Other Respiratory Virus Vaccine, Medical Research Council (1964): Clinical trials of oil-adjuvant influenza vaccines, 1960-3. Brit. Med. J., ii, 267-271.

Cutler, J. C., Lesesne, L. and Vaughn, I. (1962): Use of poliomyelitis virus vaccine in light mineral oil adjuvant in a community immunization program and report of reactions encountered. J. Allergy, 33, 193-209.

Fischel, E. E., Kabat, E. A., Stoerk, H. C. And Bezer, A. E. (1952): The role of tubercle bacilli in adjuvant emulsions on antibody production to egg albumin. J. Immunol., 69, 611-618.

Freund, J., Thomson, K. J., Hough, H. B., Sommer, H. E. and Pisani, T. M. (1948): Antibody formation and sensitization with the aid of adjuvants. J. Immunol., 60, 383-398.

Friedewald, W. F. (1944): Adjuvants in immunization with influenza virus vaccines. J. Exptl. Med., 80, 477-491.

Goto, N., Kuratsuka, K., Shimazaki, Y. and Funasaka, I. (1972): Physicochemical properties of oil adjuvants and the production of precipitin and skin reactions to ovalbumin in the guinea pig. Medicine and Biology, 84, 139-143 (in Japanese).

Goto, N., Shimazaki, Y., Funasaka, I. and Kuratsuka, K. (1973): Relations between physicochemical properties of incomplete oil adjuvants and histological reactions in the guinea pig. Medicine and Biology, 87, 1-5 (in Japanese).

Goto, N., Shimazaki, Y., Funasaka, I. And Kuratsuka, K. (1974a): Extreme differences in physicochemical properties of incomplete oil adjuvants and the production of precipitin and skin reaction in the guinea pig. Medicine and Biology, 88, 11-14 (in Japanese).

Goto, N., Shimazaki, Y., Funasaka, I. and Kuratsuka, K. (1974b): Comparative observation of histological reactions in the guinea pig injected with incomplete oil adjuvants of extremely different physicochemical properties. Medicine and Biology, 89, 29-33 (in Japanese).

Grayston, J. T., Wang, S. P., Woolridge, R. L. and Alexander, E. R. (1964): Prevention of trachoma with vaccine. Arch. Environ. Health, 8, 518-526.

Hardegree, M. C. ANd Pittman, M. (1967): Influence of antigens on release of free fatty acids from Arlacel A (mannide monooleate). Proc. Soc. Exptl. Biol. Med., 123, 179-184.

Henle, W. ANd Henle, G. (1945): Effect of adjuvants on vaccination of human beings against influenza. Proc. Soc. Exptl. Biol. Med., 59, 179-181.

Herbert, W. J. (1968): The mode of action of mineral-oil emulsion adjuvants on antibody production in mice. Immunology, $14,301-318$.

Hilleman, M. R., Hampil, B. AND Sweet, B. H. (1963): Poliovirus vaccines in mineral oil adjuvant. I. Animal toxicity and serologic response data. J. Allergy, 34, 413-419.

Kuratsuka, K. (1970): Proceedings of the 2nd Meeting of the Research Committee on SP and Adjuvant Vaccine of influenza. Association of Bacteriological Producers, Tokyo (in Japanese).

Kurokawa, M., Kuratsuka, K., Goto, N., Yoshikawa, T. and Ogawa, H. (1967): Proceedings of the 6th Meeting of the Research Committee on Adjuvant Vaccine of Influenza. Association of Bacteriological Producers, Tokyo (in Japanese).

Laufer, A., Tal, C. AND Behar, A. J. (1959): Effect of adjuvant (Freund's type) and its components on the organs of various animal species. A comparative study. Brit. J. Exptl. Pathol., 40, 1-7.

Maclennan, R., Schofield, F. D., Pittman, M., Hardegree, M. C. and Barile, M. F. (1965): Immunization against neonatal tetanus in New Guinea. Antitoxin response of pregnant women to adjuvant and plain toxoids. Bull. WHO, 32, 683-697.

Meiklejohn, G. (1962): Adjuvant influenza adenovirus vaccine. J. Am. Med. Assoc., 179, 594597.

Ogonuki, H., Hashizume, S. And Abe, H. (1967): Histopathological tests of tissues in the sites 
of local reactions caused by the injection of oil-adjuvant cholera vaccine. International Symposium on Adjuvants of Immunity, Utrecht 1966; Symp. Series Immunobiol. Standard., $6,125-128$.

Philippines Cholera Committee (1965): A controlled field trial of the effectiveness of cholera and cholera El Tor vaccines in the Philippines. Preliminary report. Bull. WHO, 32, 603-625.

Salk, J. E., Lewis, L. J., Youngner, J. S. And BennetT, B. L. (1951): The use of adjuvants to facilitate studies on the immunologic classification of poliomyelitis viruses. Am. J. Hyg., 54, 157-173.

SNyder, J. C., Bell, S. D. JR., Murray, E. S. ANd Nichols, R. L. (1966): Reactions among infants immunized intramuscularly with typhoid vaccine in adjuvant. J. Bacteriol., 91, 902.

Steiner, J. W., Langer, B. And Schatz, D. L. (1960): The local and systemic effects of Freund's adjuvant and it's fractions. Arch. Pathol., 70, 424-434.

Vaughan, M., Berger, J. E. and Steinberg, D. (1964): Hormone-sensitive lipase and monoglyceride lipase activities in adipose tissue. J. Biol. Chem., 239, 401-409.

Watanabe, J. (1959): The reactions of skin tissues to the fatty acids in guinea pigs. Tr. Soc. Path. Jap., 48, 1375-1392 (in Japanese).

White, R. G. ANd Herbert, W. J. (1975): Hypersensitivity to mineral oil in the domestic fowl. Immunology, 28, 925-938.

Woodhour, A. F., Jensen, K. E. and Warken, J. (1961): Development and application of new parenteral adjuvants. V. Comparative potencies of influenza vaccines emulsified in various oils. J. Immunol., 86, 681-689. 